Economic and Environmental Geology

Research Paper

\title{
Relationships of Chemical Elements and their Environmental Impacts in Groundwater, Soil, and Fodder Plants in Arid Land
}

\author{
Ali Hamdan ${ }^{*}$ Hassan Khozyem, Eman Elbadry \\ Geology Department, Faculty of Science, Aswan University \\ *Corresponding author : alielaraby1@aswu.edu.eg; alielaraby1@yahoo.com
}

\section{ARTICLE INFORMATION}

Manuscript received 25 March 2021

Received in revised form 27 May, 2021

Manuscript accepted 27 May 2021

Available online 28 June 2021

DOI : http://dx.doi.org/10.9719/EEG.2021.54.3.331

\section{Research Highlights}

- Mutual relationships of chemical elements in three important environmental elements (groundwater, soil, and fodder plants) obtained in arid land.

- The environmental monitoring, related hazards, and distributions of both heavy metals $(\mathrm{Cd}, \mathrm{Ni}, \mathrm{Fe}, \mathrm{Mn}, \mathrm{Pb}$, and $\mathrm{Zn})$ and major elements $(\mathrm{Ca}, \mathrm{Mg}, \mathrm{Na}$, and $\mathrm{K})$ in groundwater, soil, and Alfalfa plants were identified.

- Groundwater quality which depends completely on it to cover all needs were assessed and determined. The high concentration of elements in groundwater impacted both plants and soil.

\begin{abstract}
The relationship of both heavy metals and major elements in soil, plants, and groundwater was studied in a hyper-arid area and depends completely on the groundwater to cover its all needs. The study reviles that $27.3 \%$ of the studied groundwater was strongly acidic and has very low $\mathrm{pH}$ values $(<\mathrm{pH} 5.5)$. The groundwater has a serious corrosion effect on the metallic infrastructure, a negative effect on the plant growth rate, and an increase in soil degradation and acidity. The distribution of both heavy metals (Cd, Ni, $\mathrm{Fe}, \mathrm{Mn}$, $\mathrm{Pb}$, and $\mathrm{Zn}$ ) and major elements $(\mathrm{Ca}, \mathrm{Mg}, \mathrm{Na}$, and $\mathrm{K})$ in groundwater, soil, and Alfalfa plants are identical. The high concentration of elements in groundwater impacted both plants and soil. In general, not all the studied groundwater is suitable for irrigation or day-life uses; therefore, a pre-use treatment is necessary for most of the studied sites.
\end{abstract}

Keywords : Dakhla oasis, groundwater, heavy metals, fodder plants

Citation: Hamdan, A., Khozyem, H., Elbadry, E. (2021) Relationships of Chemical Elements and their Environmental Impacts in Groundwater, Soil, and Fodder Plants in Arid Land. Korea Economic and Environmental Geology, v.54, p.331-352, doi:10.9719/ EEG2021.54.3.331.

This is an Open Access article distributed under the terms of the Creative Commons Attribution Non-Commercial License (http://creativecommons.org/ licenses/by-nc/3.0) which permits unrestricted non-commercial use, distribution, and reproduction in any medium, provided original work is properly cited. pISSN 1225-7281; eISSN 2288-7962/@2021 The KSEEG. Printed by Hanrimwon Publishing Company. All rights reserved. 


\section{Introduction}

Groundwater considers as the only water source for drinking and plant irrigation in remote arid areas. The chemical composition of the groundwater continues changing its flow path, these changes are based on the ability to dissolve the aquifer substances. The lithology, mineral composition, and associated elements of the waterbearing layers are considered an anthropogenic pollutant. The high levels of major elements, heavy metals, or any pollutants in groundwater have a direct effect on human life. Also, the concentration of heavy metal has a direct effect on soil, animals, and consumers feeding on these plants as well as human food safety issues and potential health risks (McLaughlin et al., 1999).

Many arid areas depend on groundwater as the initial source of freshwater. One of the best examples in Egypt is El-Dakhla oasis in which the groundwater is the main source of freshwater used for agriculture and day-life uses. Several problems were observed including the low quality of groundwater that limits its usage, the effect of water salinity and acidity on the soil and infrastructures, and limitation of crops that can be planted based on this groundwater. Most of the cultivated land in El-Dakhla oasis is planted with Alfalfa and balm trees.

The Alfalfa plant (Medicago sativa) consider as one of the most essential forage crops in the world and is principally used as hay, silage, and pasture to feed livestock (Hawkins and $\mathrm{Yu}$ 2018). Alfalfa can grow in arid and semi-arid areas and conditions. This due to its relatively deep root system and it considers as a crop that is tolerant to water deficit (Lei et al., 2017; Zhang et al., 2019). Alfalfa can grow in a wide range of soils and under several growing conditions, including nutrient-poor soils (Lei et al., 2017). Alfalfa is suitable to produce stable yields under different stressful environments and conditions like salinity, as well as in the light of changing climate (El-Ramady et al., 2020). Alfalfa (Medicago sativa) is a high-quality forage and green manure crop. It is large spread growth in all places and is welladapted to reclaimed agricultural lands in Egypt. Currently, there are 200-300,000 acres of alfalfa planted in Egypt and acreage is rising each year (Shebl et al., 2008).

The relationships between groundwater salinity, ground- water depth, soil salinity, and plant community were studied in an arid area of China. The distribution and composition of plant communities are affected by groundwater salinity, groundwater depth, soil moisture, distances from the river, electrical conductivity, soil $\mathrm{pH}, \mathrm{Ca}^{2+}, \mathrm{Mg}^{2+}, \mathrm{Na}^{+}, \mathrm{K}^{+}$, $\mathrm{CO}_{3}{ }^{2-}, \mathrm{Cl}^{-}$, and $\mathrm{SO}_{4}{ }^{2-}$ (Zeng et al., 2020). In arid regions, the interaction and relation between plants and groundwater are very important for sustainable groundwater use and the preservation of a healthy ecosystem (Yin et al., 2015). Water, soil, and vegetable plant analyses were used for assessing the concentration of the arsenic that uptake by vegetable plants grown in soils contaminated by acidic mine water. Using the vegetables grown in this area with a high arsenic concentration (hazard quotient (HQ) of 2.7) may cause human health risk (Qin et al., 2021).

The groundwater in arid regions has essential roles in vegetation ecology. Certainly, the contribution of groundwater to plant transpiration may be critical in ecosystems with temporary or permanent water deficits (Lubczynski 2009; Barbeta and Peñuelas 2017). In arid regions, the interaction and relation between plants and groundwater show good consistency (Yin et al., 2015; Ren et al., 2017; Li et al., 2019; Maihemuti et al., 2021). Shah et al. (2013) study the relationship of the heavy metal concentrations in medicinal plants and soil. The results indicate that concentration levels of the heavy metals were found in the ascending order as $\mathrm{Pb}<\mathrm{Cr}<\mathrm{Ni}<\mathrm{Cu}<\mathrm{Mn}<\mathrm{Zn}<\mathrm{Fe}$. The used plants accumulate heavy metals in their shoot system and roots at different levels which causes many problems in medical industries and human health risks.

The hydrogeochemistry of groundwater and soil, as well as their relations in arid regions, were studied and showed a very strong correlation for major cations $(\mathrm{Na}, \mathrm{K}, \mathrm{Ca}$, and $\mathrm{Mg}$ ) and the heavy metals ( $\mathrm{Fe}, \mathrm{Mn}, \mathrm{Co}, \mathrm{Pb}$, and $\mathrm{Zn}$ ) in both water and soil (Shomar 2015). Defo et al. (2015) investigate the heavy metals concentrations in groundwater and soils within the Ntem watershed in Yaoundé (Cameroon), for monitoring and assessment of the risk on the human health. They found that the concentrations of $\mathrm{Cr}, \mathrm{Ni}, \mathrm{Cd}$, and $\mathrm{Pb}$ in groundwater and soils were generally high compared to the upper limits allowable for soils and drinking water. The concentrations of all heavy metals were higher in soil than groundwater, and these may indicate the high 
affinity between geochemical properties of soils and elements. Water, soil, and vegetable analyses were used for assessing the concentration of the heavy metal that uptake by cauliflower plants grown in integrated industrial effluent irrigated soils in Haridwar, India. The results show that the heavy metals accumulated in the selected vegetables. The heavy metals content of water, soils, and cauliflower plants were found in the ascending order as $\mathrm{Cd}<\mathrm{Cr}<\mathrm{C}<\mathrm{Zn}$ $<\mathrm{Mn}<\mathrm{Fe}$ (Kumar et al., 2019). In a semi-arid region of India, groundwater quality for irrigation and drinking purposes was monitored and studied. The water quality indexes as residual sodium carbonate (RSC), sodium adsorption ratio (SAR), electrical conductivity (EC), sodium percent (SP), permeability index (PI), Kelly's ratio (KR), and magnesium ratio $(\mathrm{MH})$ were used for groundwater assessment (Kumari and Rai 2020). As groundwater resources are among the primary factors for ecological preservation and sustainable development in arid regions, excessive exploitation of groundwater resources could lead to ecosystem degradation (Huang et al., 2019; Yin et al., 2015). Thus, groundwater is a significant driving factor for plant diversity and distribution in arid areas worldwide (Richard et al., 2013; Zhang et al., 2018).

Different studies show the possible risk to human health due to the accumulation of heavy metals in plants derived from different sources as irrigated water and/or soils (Chauhan and Chauhan 2014; Balkhair and Ashraf 2016; Alghobar and Suresha 2017; Chaoua et al., 2019).

This work aims to study the influence of major elements and heavy metals content in the soil, fodder plants (Alfalfa Medicago sativa), and groundwater at El-Dakhla oasis. In this study, groundwater properties (chemical and physiochemical) and their effect and behavior in the field environment (soil and Alfalfa plants) were recorded.

\section{Geological and Hydrogeological Setting}

El-Dakhla Oases is one of the major Oases in the New Valley governorate, Egypt, and is located $800 \mathrm{~km}$ southwest of Cairo $\left(28^{\circ} 00^{\prime}-29^{\circ} 30^{\prime} \mathrm{E}-25^{\circ} 25^{\prime}-26^{\circ} 00^{\prime}\right.$ N; Fig. 1). El-Dakhla occupies an area of equal 120500 $\mathrm{km}^{2}$ that has many populations exceeds 82000 persons. In the formal time, about 520 springs and wells at all Oases in Egypt were productive, but recently many of them have dried out, and reset is work with pumps only (Sefelnasr 2002).

Geomorphologically, El-Dakhla can be considered as a fifth-order mega depression in Egypt. The main topographic feature is the escarpment located in the northern part of the oasis depression and extends about $250 \mathrm{~km}$ in the
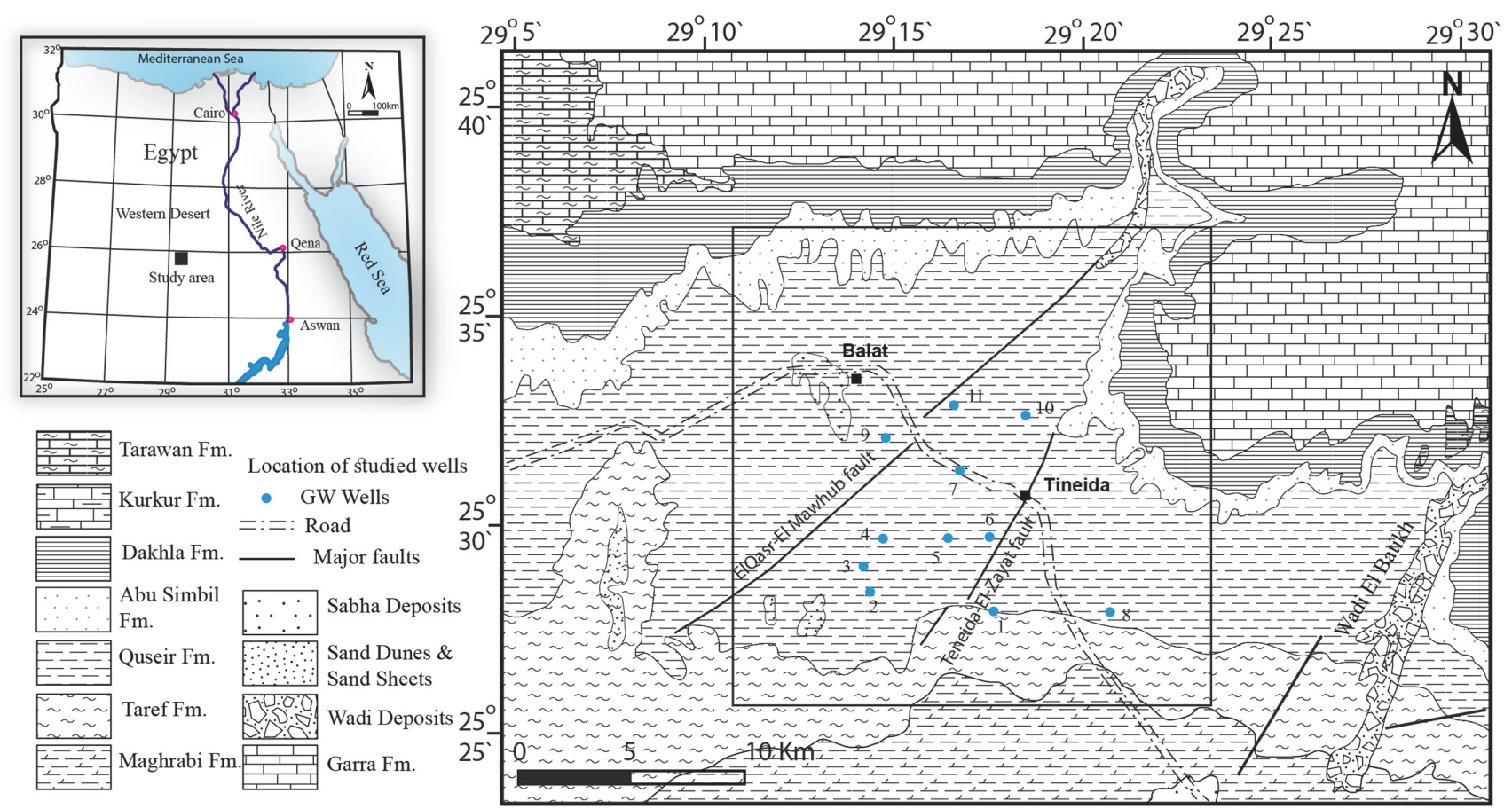

Fig. 1. Geological map of the El-Dakhla basin (modified after Conoco, 1987), together with location base map of the studied samples. 
direction of WNW-ESE. The scarp is formed of Upper Cretaceous to Paleocene marine shale that overlain by limestone and chalky limestone of early Eocene age. The maximum elevation of this scarp is recorded in the northeast of Tenieda village (580 $\mathrm{m}$ above the sea level) (Wycisk 1994).

The sedimentary cover of El-Dakhla oasis is formed of several late Mesozoic-Early Cenozoic lithostratigraphic formations (Fig. 1) which are divided into two main groups. The first is predominantly sandstone with several marine intercalations of Jurassic-Campanian age and the second is open marine sequences composed of shale, limestone, chalk, and phosphate dated to Campanian Lower Eocene (Hermina 1990; Said 1990).

Hydrogeologically, the groundwater in El-Dakhla oasis is belonging to and part of the Nubian Sandstone Aquifer System. Its average thickness in El-Dakhla area is $1386 \mathrm{~m}$ (Heinl and Thorweihe 1993). The Nubian Aquifer includes three water-bearing formations (Six Hills, Sabaya, and Taref; Gad et al., 2011). The lower unit (more than $1000 \mathrm{~m}$ Six Hills Fm.) is sandwiched between basement rocks and Abu Ballas claystone that gave this interval the confined nature. It is followed upward by the second confining unit (275m Sabaya Fm.) that's capped by Maghraby claystone and shale acting as seal rock. The upper unit is (111m) Taref Fm and covered by phosphate beds and variegated shale. The thickness of the three units increases west and southward due to faults that throw to the south and west directions (Gad et al., 2011). In El-Dakhla area, only the lower two water-bearing intervals are recorded.

\section{Materials and Methods}

Three types of samples collected and analyzed from different places covering the study area represented groundwater, soil, and Alfalfa plant samples (Fig. 1). The samples were collected from 11 sites covering the study area during January 2016. Three different sample categories were collected, groundwater, soil, and Alfalfa plants (Medicago sativa). The groundwater samples collected from the wells that the Alfalfa plants irrigated from them as well as the soil samples collected from the same places. For all sites, all three sample categories (groundwater, soil, and Alfalfa plants) were collected from the same place. The groundwater samples were obtained from wells only after an adequate time of pumping to ensure that the samples represent the original groundwater source and thin they are stored in plastic bottles. Some measurements were carried out after groundwater samples were collected directly as $\mathrm{pH}, \mathrm{EC}$, temperature.

The Alfalfa (Medicago sativa) is chosen as plant samples where it has large spread growth in all places in the study area, also it has a high growth rate as well as high biomass. The alfalfa shoot systems (include the organs such as leaves, buds, stems, and flowers) were collected and used for this study. The samples were washed with distilled water. Then they were dried in an oven at about $80-100{ }^{\circ} \mathrm{C}$ followed by grinding, using pistol mortar. The grinded samples were then stored in clean, dried, and decontaminated plastic bags. The plant samples were subjected to digestion process according to (Application Bulletin Metrohm, Method No.114/1e), as follows: (i) One gram grinded powder of the shoot system of each plant sample was transferred to a $100 \mathrm{ml}$ beaker, (ii) $16 \mathrm{ml}$ $\mathrm{H}_{2} \mathrm{SO}_{4}(95 \%)$ was poured into it and the resulting mixture was heated to $200{ }^{\circ} \mathrm{C}$, till the mixture attained a brown color, (iii) Add $4 \mathrm{ml} \mathrm{H} \mathrm{H}_{2} \mathrm{O}_{2}$ (35\%) through a dropping funnel, as the reaction finished another $4 \mathrm{ml} \mathrm{H}_{2} \mathrm{O}_{2}$ (35\%) was added, (iv) The mixture was heated again, and addition of $\mathrm{H}_{2} \mathrm{O}_{2}$ had to be repeated at $200^{\circ} \mathrm{C}$ temperature till the digested solution stayed clear, (v) After cooling, the content was transferred to a $100 \mathrm{ml}$ volumetric flask and the final volume was made up using deionized water, and (vi) The solutions stored in dry and clean plastic bottles.

Soil samples were collected without a specific grid pattern within the study area. soil samples were gathered from the top $20 \mathrm{~cm}$ surface soil layer. The samples were stored in cleaned plastic bags. Pieces of pebbles, plant roots and sticks were removed from the samples. All soil samples were air-dried, crushed and sieved to fine size by passed through $2 \mathrm{~mm}$ sieves before the soil analyses.

The following hydrochemical parameters were measured and calculated in water samples: temperature, electrical conductivity (EC), $\mathrm{pH}$, total hardness (TH), total dissolved solids (TDS), total suspended solids (TSS), major constituents, and heavy metals.

Chloro-alkaline indices (CAI) determine the ion exchange that can happen between the groundwater and its aquifer material or other rocks in contact during its flow path or travel process (Schoeller 1967). CAI1 \& 2 estimated using 
the following equations:

$$
\begin{aligned}
& \mathrm{CAI} 1=\frac{(C L)-(\mathrm{Na}+\mathrm{K})}{(\mathrm{Cl})} \\
& \mathrm{CAI} 2=\frac{(\mathrm{CL})-(\mathrm{Na}+\mathrm{K})}{\left(\mathrm{SO}_{4}+\mathrm{HCO}_{3}\right)}
\end{aligned}
$$

All values are expressed in meq/l.

Langelier Saturation Index (LSI) and Ryznar Stability Index (RSI) used to detect the groundwater corrosivity in the study area and calculated by using the following equations:

$$
\begin{aligned}
\mathrm{LSI} & =\mathrm{pH}-\mathrm{pHs} \\
\mathrm{RSI} & =2 \mathrm{pH}-\mathrm{pH}
\end{aligned}
$$

Where (LSI) is the Langelier Saturation Index and (RSI) is the Ryznar Stability Index

$\mathrm{pHs}$ calculated by using the following equation (Edstrom 1998):

$$
\mathrm{pHs}=(9.3+\mathrm{A}+\mathrm{B})-(\mathrm{C}+\mathrm{D})
$$

Where;

$\mathrm{A}=\left(\log _{10}(\mathrm{TDS} \mathrm{mg} / \mathrm{L})-1\right) / 10$.

$\mathrm{B}=\left(-13.2 \log _{10}(\mathrm{~T}+273)\right)+34.55 . \mathrm{T}$ is the temperature in ${ }^{\circ} \mathrm{C}$.

$\mathrm{C}=\left(\log _{10}\right.$ (calcium hardness $\left.)\right)$ - 0.4. Calcium hardness in $\mathrm{mg} / \mathrm{L}\left(\right.$ as $\left.\mathrm{CaCO}_{3}\right)$.

$\mathrm{D}=\log _{10}$ (alkalinity or temporary hardness in $\mathrm{mg} / \mathrm{L}$ ).

The Sodium Adsorption Ratio (SAR) determined using the following equation (US Salinity Laboratory 1954):

$$
S A R=\frac{r N a^{+}}{\sqrt{\left(\frac{r C a^{2+}+r M g^{2+}}{2}\right)}}
$$

$\mathrm{r}=$ the elements are in epm.

Sodium percent $(\mathrm{Na} \%)$ computed by:

$$
\mathrm{Na} \%=\frac{r N a^{+}+r K^{+}}{r \mathrm{Ca}^{2+}+r \mathrm{Mg}^{2+}+r N a^{+}+r K^{+}} \times 100
$$

where all elements are in meq/L.

The analytical work for the different kinds of samples was conducted at the Unit of Environmental Studies and Development lab, Aswan University, which has an accreditation ISO/IEC 17025:2005.

Cluster analysis is used to detect the groups of samples with similar patterns of element concentrations and it is an important tool in multivariate statistical analysis. It was performed by using MINITAB software package for Windows (Minitab.v16.1.1).

\section{Results and Discussion}

\subsection{Results}

Most of the groundwater is dominant by $\mathrm{Ca}-\mathrm{Mg}-\mathrm{SO}_{4}-\mathrm{Cl}$ type $(90.3 \%)$ and $\mathrm{Na}-\mathrm{Cl}-\mathrm{SO}_{4}$ type $(9.7 \%)$ as detected from the Piper diagram. The groundwater is characterized by the dominance of anions $\left(\mathrm{SO}_{4}{ }^{2-}\right.$ from over $\mathrm{Cl}^{-}$and $\mathrm{HCO}_{3}{ }^{-}$) while cations $\left(\mathrm{Na}^{+}, \mathrm{Ca}^{+2}\right.$, and $\left.\mathrm{Mg}^{+2}\right)$ are showing a mixed zone. In groundwater. the total suspended solids (TSS) varied from 0.046 to $0.249 \mathrm{mg} / \mathrm{L}$; its temperature varied from 27.5 to $030.3 \mathrm{mg} / \mathrm{L}$, and the total hardness $(\mathrm{TH})$ varied from 233.8 to $1187 \mathrm{mg} / \mathrm{L}$ (Table 1).

The hydrochemical parameter $\mathrm{Na}+\mathrm{K} /(\mathrm{Na}+\mathrm{K}+\mathrm{Ca})(\mathrm{Gibbs}$ 1970) was used for rock-water interaction diagram in ElDakhla area (Fig. 2). its values vary from 0.263 to 0.802 .

By using cluster analysis, three main groups of the elements were detected each group has several elements that behave similarly in the aquatic medium, Fe-Mn group, contains two variables (Fe and $\mathrm{Mn}$ ) with a linkage distance $0.02, \mathrm{Ni}-\mathrm{Zn}$ group, with a linkage distance of 0.043 whereas $\mathrm{Cu}$ belongs to this group, and $\mathrm{Pb}-\mathrm{Cd}$ group, composed of two variables with linkage distance 0.6.

The chloro-alkaline indices (CAI1 and CAI2) are used to determine the ion exchange between the groundwater and the water-bearing layers through the flow path (Fig. 3). The (CAI1) values vary from -3.71 to 0.64 and the (CAI2) values are from -0.37 to 1.55 . The $\mathrm{pH}$ values vary from 3.43 to 6.69 in groundwater with an average of 5.69. High acidity affects the plant growth irrigated by it (Fig. 4).

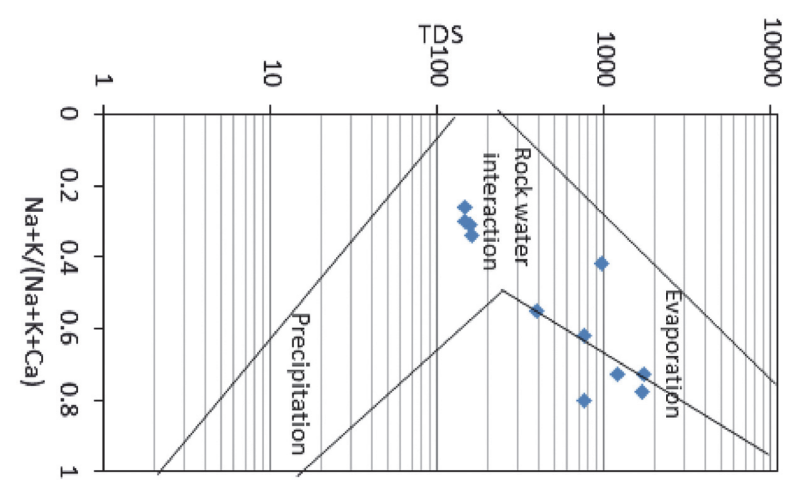

Fig. 2. Rock-water interaction diagram for El-Dakhla area. 
Table 1. Physico-chemical data of groundwater samples

\begin{tabular}{|c|c|c|c|c|c|c|c|c|c|c|c|c|}
\hline S. no. & $\begin{array}{c}\mathrm{Ca} \\
\mathrm{mg} / \mathrm{L}\end{array}$ & $\begin{array}{c}\mathrm{Mg} \\
\mathrm{mg} / \mathrm{L}\end{array}$ & $\begin{array}{c}\mathrm{Na} \\
\mathrm{mg} / \mathrm{L}\end{array}$ & $\begin{array}{c}\mathrm{K} \\
\mathrm{mg} / \mathrm{L}\end{array}$ & $\begin{array}{l}\mathrm{HCO}_{3} \\
\mathrm{mg} / \mathrm{L}\end{array}$ & $\begin{array}{c}\mathrm{SO}_{4} \\
\mathrm{mg} / \mathrm{L}\end{array}$ & $\begin{array}{c}\mathrm{Cl} \\
\mathrm{mg} / \mathrm{L}\end{array}$ & $\begin{array}{c}\mathrm{Pb} \\
\mu \mathrm{g} / \mathrm{L}\end{array}$ & $\begin{array}{c}\mathrm{Cd} \\
\mathrm{mg} / \mathrm{L}\end{array}$ & $\begin{array}{c}\mathrm{Ni} \\
\mathrm{mg} / \mathrm{L}\end{array}$ & $\begin{array}{c}\mathrm{Zn} \\
\mathrm{mg} / \mathrm{L}\end{array}$ & $\begin{array}{c}\mathrm{Cu} \\
\mathrm{mg} / \mathrm{L}\end{array}$ \\
\hline 1 & 100 & 109 & 287.4 & 36.71 & 12.2 & 709.9 & 426 & 5.42 & 0.0001 & 0.3638 & 0.2873 & 0.0322 \\
\hline 2 & 80.0 & 240 & 310.7 & 39.66 & 47.0 & 850.51 & 701 & 28.3 & nd & 0.476 & 0.4434 & 0.045 \\
\hline 3 & 100 & 180 & 298.6 & 31.95 & 30.5 & 820.61 & 532.2 & nd & nd & 0.3544 & 0.2065 & 0.0312 \\
\hline 4 & 100 & 48.0 & 37.0 & 24.35 & 152.5 & 376.16 & 28.4 & 6.32 & nd & 0.0347 & nd & 0.0129 \\
\hline 5 & 70.0 & 39.6 & 19.6 & 26.28 & 122 & 177.78 & 85.2 & 5.24 & nd & 0.0343 & nd & 0.0087 \\
\hline 6 & 40.0 & 90.0 & 172.1 & 22.88 & 122 & 215.76 & 379.8 & nd & nd & 0.0253 & nd & 0.0063 \\
\hline 7 & 80.0 & 24.0 & 18.62 & 23.91 & 122 & 204.85 & 35.5 & nd & nd & 0.0204 & nd & 0.0061 \\
\hline 8 & 140 & 60.0 & 102.4 & 26.73 & 30.5 & 612.53 & 106.5 & 30.9 & 0.0034 & 0.4512 & 0.1979 & 0.0172 \\
\hline 9 & 70.0 & 60.0 & 85.0 & 19.53 & 42.7 & 385.05 & 138.4 & 40.9 & 0.0002 & 0.0422 & nd & 0.0116 \\
\hline 10 & 60.0 & 20.4 & 18.3 & 28.51 & 122 & 147.07 & 28.4 & 17.8 & 0.0014 & 0.04 & nd & 0.0145 \\
\hline 11 & 60.0 & 24.0 & 95.0 & 32.58 & 42.7 & 249.7 & 142 & 23.9 & 0.002 & 0.0348 & nd & 0.0139 \\
\hline Min & 40.0 & 20.4 & 18.3 & 19.53 & 12.2 & 147.07 & 28.4 & 5.24 & 0.0001 & 0.0204 & 0.1979 & 0.0061 \\
\hline Max & 140 & 240 & 310.7 & 39.66 & 152.5 & 850.51 & 701.0 & 40.90 & 0.0034 & 0.476 & 0.4434 & 0.045 \\
\hline Mean & 81.82 & 81.36 & 131.34 & 28.46 & 76.92 & 431.81 & 236.6 & 19.85 & 0.0014 & 0.1706 & 0.2838 & 0.0181 \\
\hline S. no. & $\begin{array}{c}\mathrm{T} \\
{ }^{\circ} \mathrm{C}\end{array}$ & \multicolumn{2}{|c|}{$\mathrm{pH}$} & LSI & RSI & \multicolumn{2}{|c|}{$\begin{array}{c}\mathrm{EC} \\
\mu \mathrm{S} / \mathrm{cm}\end{array}$} & $\begin{array}{c}\text { TDS } \\
\mathrm{mg} / \mathrm{L}\end{array}$ & $\begin{array}{c}\mathrm{TSS} \\
\mathrm{mg} / \mathrm{L}\end{array}$ & \multicolumn{2}{|c|}{$\begin{array}{c}\mathrm{TH} \\
\mathrm{mg} / \mathrm{L}\end{array}$} & $\begin{array}{c}\mathrm{Na} \\
\%\end{array}$ \\
\hline 1 & 30 & \multicolumn{2}{|c|}{3.54} & -5.1 & 14 & \multicolumn{2}{|c|}{3,465} & 1,739 & 0.048 & \multicolumn{2}{|c|}{699.2} & $49.03 \%$ \\
\hline 2 & 30 & \multicolumn{2}{|c|}{3.43} & -4.7 & 13 & \multicolumn{2}{|c|}{3,403} & 1,704 & 0.081 & \multicolumn{2}{|c|}{1187} & $37.97 \%$ \\
\hline 3 & 27.5 & \multicolumn{2}{|c|}{4.06} & -4.2 & 12 & \multicolumn{2}{|c|}{2,397} & 1,203 & 0.068 & \multicolumn{2}{|c|}{990.6} & $41.09 \%$ \\
\hline 4 & 28.9 & \multicolumn{2}{|c|}{6.61} & -0.67 & 7.9 & \multicolumn{2}{|c|}{317} & 158 & 0.051 & \multicolumn{2}{|c|}{447.3} & $19.98 \%$ \\
\hline 5 & 27.5 & \multicolumn{2}{|c|}{6.65} & -0.9 & 8.55 & \multicolumn{2}{|c|}{292} & 146 & 0.083 & \multicolumn{2}{|c|}{337.8} & $18.42 \%$ \\
\hline 6 & 30 & \multicolumn{2}{|c|}{6.37} & -1.5 & 9.4 & \multicolumn{2}{|c|}{1,403} & 750 & 0.046 & \multicolumn{2}{|c|}{470.3} & $46.18 \%$ \\
\hline 7 & 29 & \multicolumn{2}{|c|}{6.36} & -1.1 & 8.6 & \multicolumn{2}{|c|}{260} & 145 & 0.049 & \multicolumn{2}{|c|}{298.5} & $19.24 \%$ \\
\hline 8 & 30 & \multicolumn{2}{|c|}{5.78} & -2.2 & 10.22 & \multicolumn{2}{|c|}{1,927} & 968 & 0.112 & \multicolumn{2}{|c|}{596.5} & $30.13 \%$ \\
\hline 9 & 30.3 & \multicolumn{2}{|c|}{6.46} & -1.6 & 9.54 & & & 396 & 0.054 & & .8 & $33.24 \%$ \\
\hline 10 & 28 & & & -1.96 & 8.54 & & & 162 & 0.249 & & .8 & $24.61 \%$ \\
\hline 11 & 29 & & & -1.5 & 9.71 & & & 765 & 0.052 & & & $49.98 \%$ \\
\hline Min & 27.5 & & & -5.1 & 7.9 & & & 145 & 0.046 & & .8 & $18.42 \%$ \\
\hline Max & 30.3 & & & -0.67 & 14 & & & 1,739 & 0.249 & & & $49.98 \%$ \\
\hline Mean & 28.80 & & & -2.31 & 10.13 & & & 739.64 & 0.08 & & 22 & $33.62 \%$ \\
\hline
\end{tabular}

$\mathrm{Nd}$ : not detected.

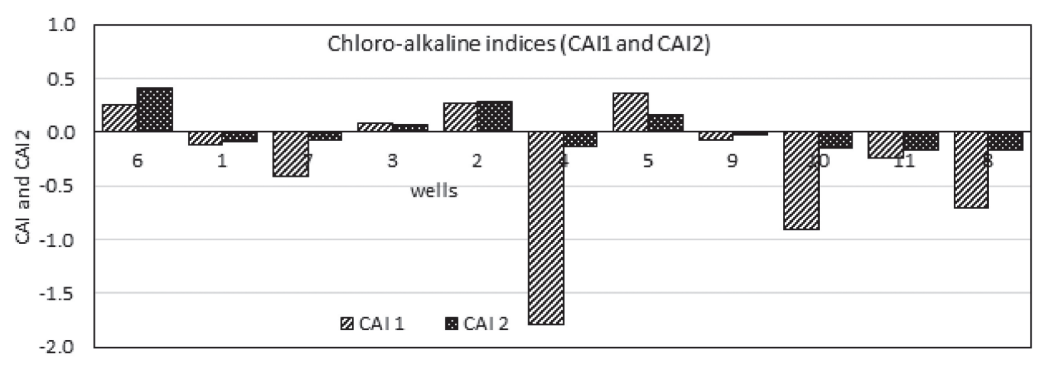

Fig. 3. Chloro-alkaline indices 1 and 2 for El-Dakhla area.

Langelier Saturation Index (LSI) is defined concerning the high concentration of calcium carbonate. Another factor, the Ryznar Stability Index (RSI) was used to detect the corrosivity in the examined groundwater (Fig. 5). It is defined about water corrosion in metal pipes and is determined using the concentration of sulfate, chloride, and bicarbonate. LSI and RSI are very important where most parts of the groundwater distribution networks and wells 


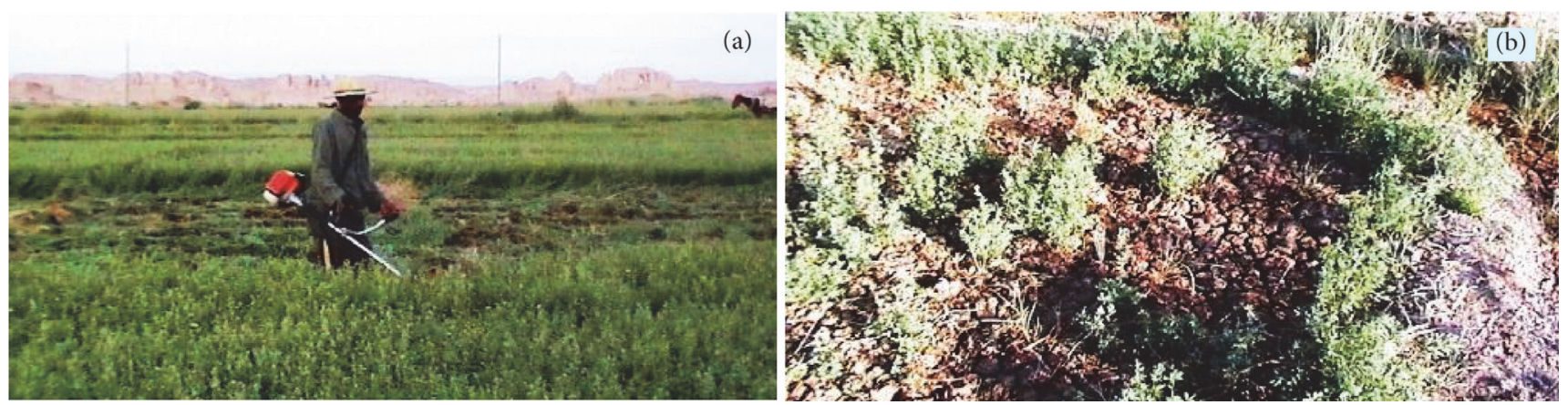

Fig. 4. Alfalfa crops in different parts affected by change of water acidity: a) Alfalfa irrigated by groundwater of normal pH; b) Alfalfa irrigated by groundwater of low $\mathrm{pH}$ and high acidity where affected in its growth.

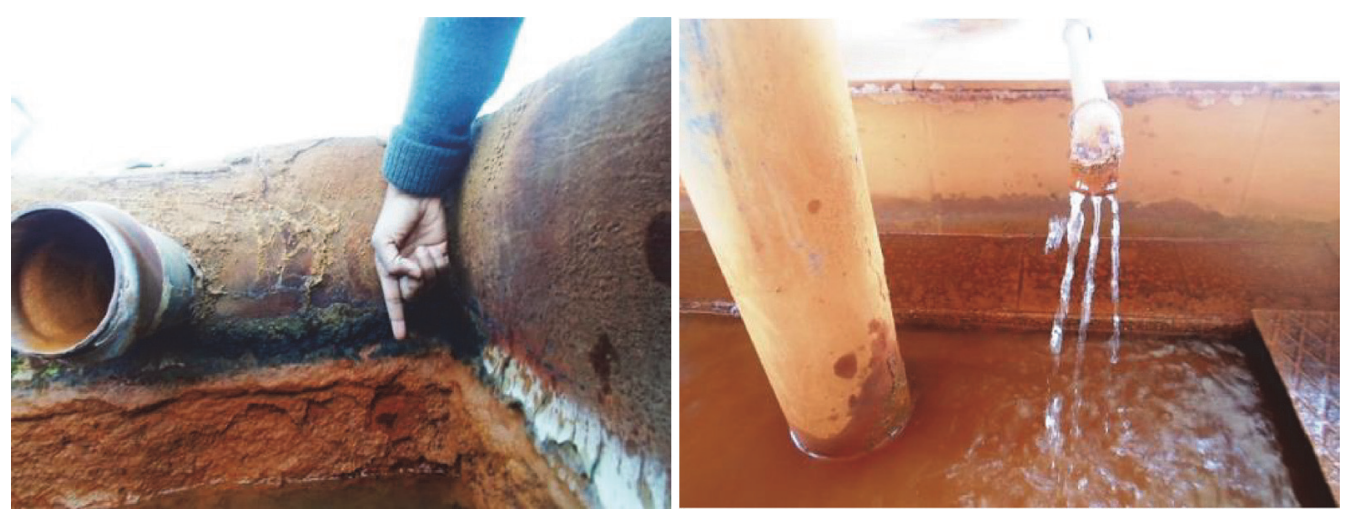

Fig. 5. Corrosions by the action of groundwater in El-Dakhla area.

equipment are made of metals. Those indices are based upon a calculated $\mathrm{pH}$ of saturation for calcium carbonate (pHs), total dissolved solids (TDS), water temperature, the concentration of calcium hardness, alkalinity, and temporary

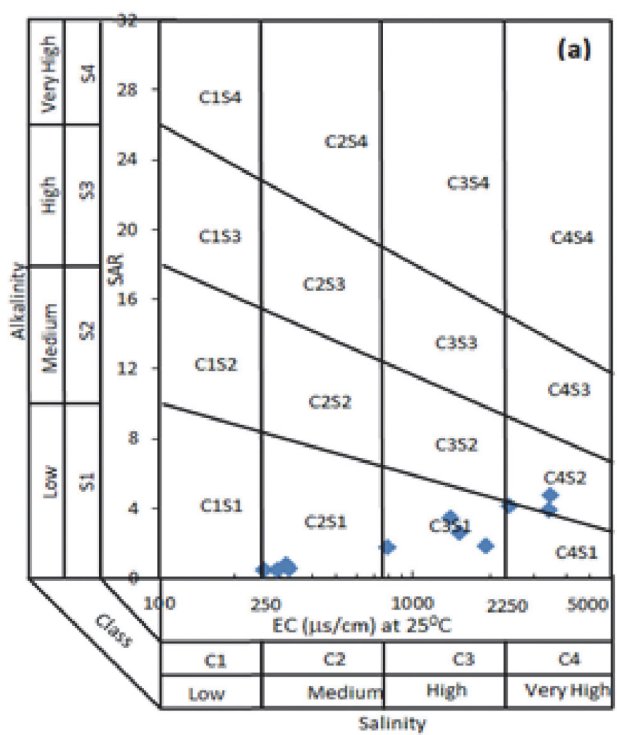

hardness (Edstrom 1998). Langelier Saturation Index (LSI) values of groundwater vary from -5.1 to -0.67 while calculated Ryznar Stability Index (RSI) values vary from 4.9 to 14.0 .

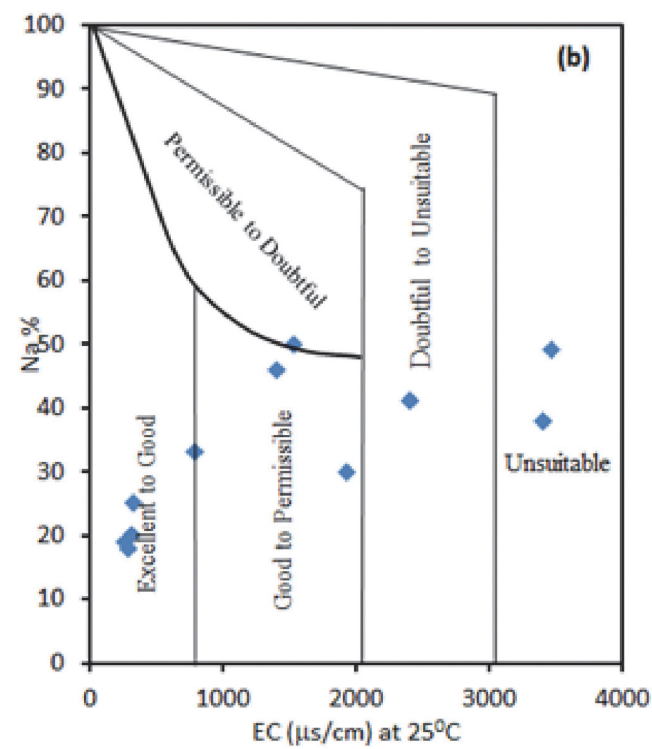

Fig. 6. Groundwater Quality: (a) after the US Salinity Laboratory (1954), (b) based on sodium per cent and electric conductivity. 
Groundwater quality for irrigation examines by plotting the sodium-adsorption ratio (SAR) and the electrical conductivity (EC) of the water samples in the diagram Figure (6.a) (After US Salinity Laboratory, 1954). The diagram indicates that the majority of groundwater in the study area (73\%) lies at C2-S1 class (low SAR with Medium salinity) and C3-S1 class (High salinity and low SAR). While $18 \%$ lies at C4-S2 class (Very high salinity with Medium SAR) and 9\% located in C4-S1 class (Very high salinity with low SAR).

Sodium percentage values and electric conductivity of groundwater at El-Dakhla Oasis plotted in Wilcox (1955) diagram (Fig. 6.b). Electric conductivity values range between 260 and $3465 \mu \mathrm{S} / \mathrm{cm}$, while sodium percentage values vary from $18.42 \%$ to $49.98 \%$.

Major ions were analyzed from the soil, Alfalfa plants, and groundwater in the study area. The calcium (Ca) values vary from 40 to $140 \mathrm{mg} / \mathrm{L}$ in groundwater, from
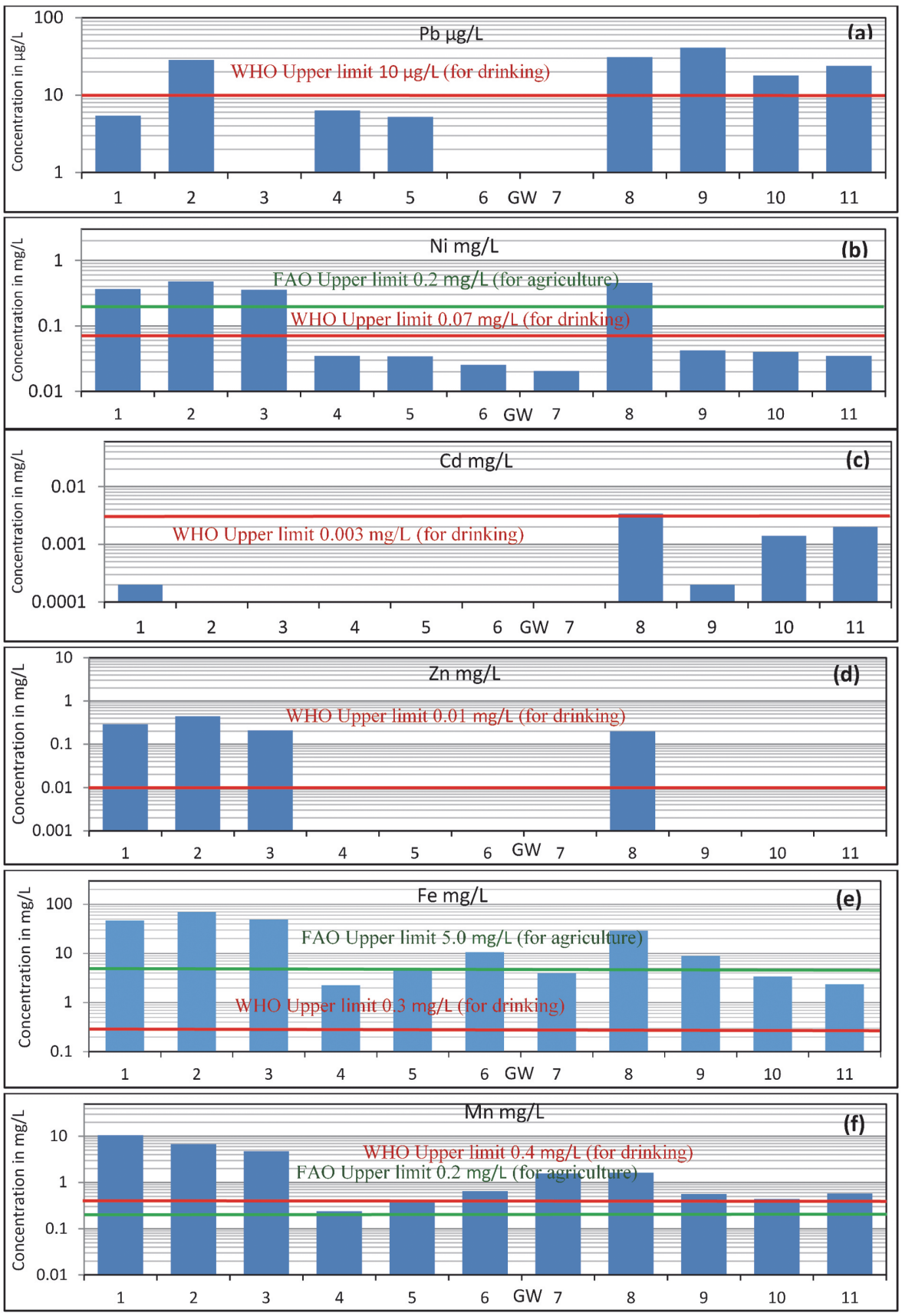

Fig. 7. Influence of heavy metal contents in groundwater: (a) Lead, (b) Nickel, (c) Cadmium, (d) Zinc, (e) Iron, and (f) Manganese. 
4000 to $8000 \mathrm{mg} / \mathrm{kg}$ in soil, and from 80 to $240 \mathrm{mg} / \mathrm{kg}$ in Alfalfa plants (Tables 1 to 3). The magnesium (Mg) values vary from 20.4 to $240 \mathrm{mg} / \mathrm{L}$ in groundwater, from 1,200 to $4,800 \mathrm{mg} / \mathrm{kg}$ in soil, and from 274.4 to $1,166 \mathrm{mg} /$ $\mathrm{kg}$ in Alfalfa plants (Tables 1 to 3).

The sodium (Na) values vary from 18.3 to $310.7 \mathrm{mg} / \mathrm{L}$ in groundwater, from 763.9 to $2,057.2 \mathrm{mg} / \mathrm{kg}$ in Soil, and from 541.6 to $39,527.1 \mathrm{mg} / \mathrm{kg}$ in Alfalfa plants (Tables 1 to 3). The potassium (K) values vary from 19.53 to $39.66 \mathrm{mg} / \mathrm{L}$ in groundwater, from $1,066.2$ to $17,060 \mathrm{mg} / \mathrm{kg}$ in Soil, and from $10,866.6$ to $34,818.8 \mathrm{mg} / \mathrm{kg}$ in Alfalfa plants (Tables 1 to 3).
In the study area in some locations, groundwater does not show any color as soon as it pumps up to the surface directly, but after a period of time, the colorless groundwater turned into red color. These colors are explained may be by the presence of iron and manganese ions or others. Also there are some problems for plant growth (as Alfalfa plants). So that, heavy metals as $\mathrm{Fe}, \mathrm{Mn}, \mathrm{Cd}, \mathrm{Ni}, \mathrm{Pb}$, and $\mathrm{Zn}$ were analyzed and assessed (Figs. 7 \& 8).

The concentrations of lead in the study area are from 0.00524 to $0.0409 \mathrm{mg} / \mathrm{L}$ in groundwater, from 3.98 to $16.04 \mathrm{mg} / \mathrm{kg}$ in soil, and from 0.85 to $20.4 \mathrm{mg} / \mathrm{kg}$ in the

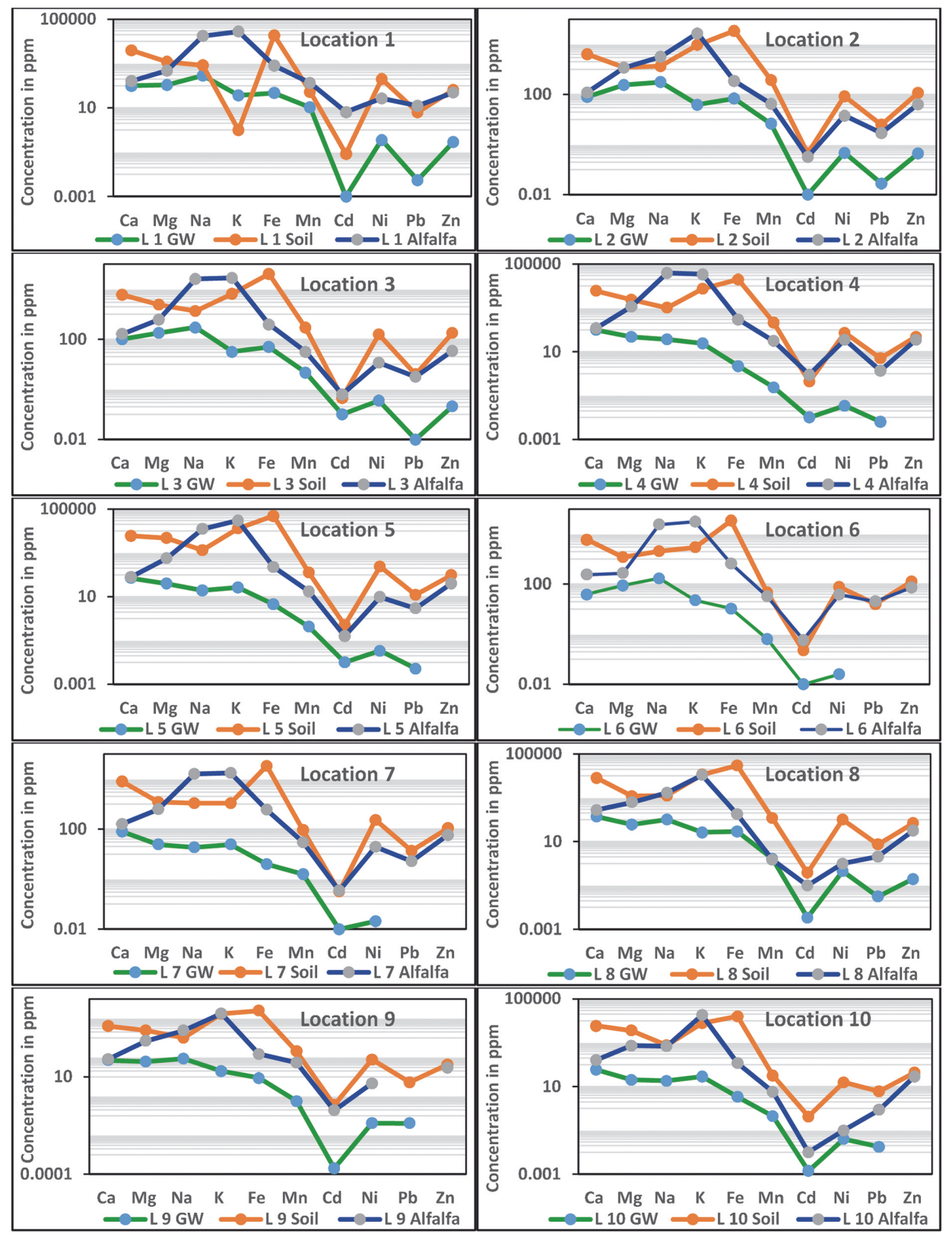

Fig. 8. Elements relationship in soil, Alfalfa plants and groundwater at different location in El-Dakhla area. 
plants (Tables 1 to 3). The value of nickel concentration in groundwater in the study area varied from 0.0204 to $0.476 \mathrm{mg} / \mathrm{L}$ (with an average of $0.1706 \mathrm{mg} / \mathrm{L}$ ) in groundwater. While in soil, varied from 15.62 to $239.2 \mathrm{mg} / \mathrm{kg}$ (with an average of $118.4 \mathrm{mg} / \mathrm{kg}$ ), and varied from 4.65 to $38.4 \mathrm{mg} / \mathrm{kg}$ (with an average of $20.09 \mathrm{mg} / \mathrm{kg}$ ) in Alfalfa plants grown in study (Tables 1 to 3 ).

The concentrations of cadmium in the study area in groundwater are $0.0001 \mathrm{mg} / \mathrm{L}$ (well no. 1) to $0.0034 \mathrm{mg} / \mathrm{L}$ (well no. 8), with an average of $0.0014 \mathrm{mg} / \mathrm{L}$ (Table 1). The concentrations of cadmium are from 0.083 to 0.501 $\mathrm{mg} / \mathrm{kg}$ in soil, and from 0.016 to $6.49 \mathrm{mg} / \mathrm{kg}$ in Alfalfa plants (Tables 2 and 3). The concentration of zinc in groundwater vary from 0.198 and $0.443 \mathrm{mg} / \mathrm{L}$, with an average of $0.284 \mathrm{mg} / \mathrm{L}$. Zinc values are from 42.43 to $174.5 \mathrm{mg} / \mathrm{kg}$ in soil and from 20.13 to $73.52 \mathrm{mg} / \mathrm{kg}$ in

Table 2. Chemical analyses and element concentrations of Alfalfa shoot system samples

\begin{tabular}{ccccccccccc}
\hline S. no. & $\begin{array}{c}\mathrm{Ca} \\
\mathrm{mg} / \mathrm{kg}\end{array}$ & $\begin{array}{c}\mathrm{Mg} \\
\mathrm{mg} / \mathrm{kg}\end{array}$ & $\begin{array}{c}\mathrm{Na} \\
\mathrm{mg} / \mathrm{kg}\end{array}$ & $\begin{array}{c}\mathrm{K} \\
\mathrm{mg} / \mathrm{kg}\end{array}$ & $\begin{array}{c}\mathrm{Fe} \\
\mathrm{mg} / \mathrm{kg}\end{array}$ & $\begin{array}{c}\mathrm{Mn} \\
\mathrm{mg} / \mathrm{kg}\end{array}$ & $\begin{array}{c}\mathrm{Cd} \\
\mathrm{mg} / \mathrm{kg}\end{array}$ & $\begin{array}{c}\mathrm{Ni} \\
\mathrm{mg} / \mathrm{kg}\end{array}$ & $\begin{array}{c}\mathrm{Pb} \\
\mathrm{mg} / \mathrm{kg}\end{array}$ & $\begin{array}{c}\mathrm{Zn} \\
\mathrm{mg} / \mathrm{kg}\end{array}$ \\
\hline 1 & 160 & 483 & $17,475.7$ & $27,877.7$ & 808.25 & 133.3 & 6.49 & 27.09 & 12.34 & 48.85 \\
2 & 120 & 1166 & $3,151.97$ & $27,882.2$ & 343.45 & 42.12 & 0.32 & 14.51 & 2.90 & 41.54 \\
3 & 160 & 611.6 & $25,893.8$ & $28,349.2$ & 392.69 & 32.05 & 0.63 & 11.57 & 3.16 & 34.36 \\
4 & 120 & 1166 & $39,527.1$ & $34,818.8$ & 300.47 & 30.91 & 0.898 & 35.65 & 1.38 & 34.4 \\
5 & 80 & 563 & $12,188.1$ & $29,839.7$ & 228.67 & 17.53 & 0.16 & 9.59 & 2.92 & 39.87 \\
6 & 240 & 274.4 & $23,998.7$ & $31,520.1$ & 659.03 & 32.22 & 0.6 & 38.44 & 20.4 & 73.52 \\
7 & 160 & 611.6 & $15,960.1$ & $17,567.6$ & 583.18 & 29.86 & 0.34 & 19.19 & 5.11 & 58.65 \\
8 & 280 & 620.2 & $1,688.64$ & 10,898 & 175.68 & 1.49 & $\mathrm{nd}$ & $\mathrm{nd}$ & 2.07 & 31.75 \\
9 & 80 & 691.6 & $2,355.74$ & 17,578 & 147.62 & 53.51 & 0.19 & 4.65 & $\mathrm{nd}$ & 29.26 \\
10 & 160 & 740.2 & 696.573 & $18,203.1$ & 116.13 & 5.75 & $\mathrm{nd}$ & $\mathrm{nd}$ & 0.85 & 29.35 \\
11 & 240 & 788.8 & 541.568 & $10,866.6$ & 152.09 & 6.89 & $\mathrm{nd}$ & $\mathrm{nd}$ & 2.15 & 20.13 \\
Min & 80 & 274.4 & 541.6 & $10,866.6$ & 116.1 & 1.50 & 0.20 & 4.70 & 0.90 & 20.1 \\
Max & 280 & 1166 & $39,527.1$ & $34,818.8$ & 808.3 & 133.3 & 6.50 & 38.4 & 20.4 & 73.5 \\
Mean & 163.64 & 701.49 & $13,043.5$ & $23,218.3$ & 355.21 & 35.06 & 1.20 & 20.09 & 5.33 & 40.15 \\
\hline
\end{tabular}

Nd: not detected.

Table 3. Chemical analyses and element concentrations of the soil samples $(\mathrm{mg} / \mathrm{kg})$

\begin{tabular}{cccccccccccc}
\hline S. no. & $\mathrm{Ca}$ & $\mathrm{Mg}$ & $\mathrm{Na}$ & $\mathrm{K}$ & $\mathrm{Fe}$ & $\mathrm{Mn}$ & $\mathrm{Cd}$ & $\mathrm{Ni}$ & $\mathrm{Pb}$ & $\mathrm{Zn}$ \\
\hline 1 & 4,000 & 1,200 & 835.16 & $\mathrm{nd}$ & $18,616.74$ & 53.56 & 0.0832 & 200.51 & 6.3574 & 64.5654 \\
2 & 4,000 & 1,200 & $1,351.14$ & $9,439.97$ & $34,215.17$ & 377.6 & 0.4488 & 85.97 & 6.136 & 115.729 \\
3 & 6,000 & 2,400 & $1,330.05$ & $6,637.85$ & $40,829.43$ & 288.83 & 0.4592 & 156.49 & 3.9866 & 174.517 \\
4 & 6,000 & 2,400 & $1,006.87$ & $7,503.61$ & $20,339.41$ & 217.88 & 0.4294 & 74.11 & 5.0704 & 48.411 \\
5 & 6,000 & 4,800 & $1,312.41$ & $12,906.3$ & $49,434.55$ & 124.28 & 0.5012 & 239.19 & 12.236 & 96.2224 \\
6 & 6,000 & 1,200 & $2,057.2$ & $2,927.33$ & $34,541.16$ & 46.07 & 0.221 & 78.44 & 16.042 & 127.688 \\
7 & 8,000 & 1,200 & $1,077.67$ & $1,066.23$ & $33,831.79$ & 89.57 & 0.3126 & 232.38 & 13.609 & 107.973 \\
8 & 8,000 & 1,200 & $1,265.51$ & $11,516.2$ & $29,863.84$ & 116.11 & 0.3738 & 101.507 & 7.3222 & 69.0046 \\
9 & 4,000 & 2,400 & $1,010.72$ & $17,060.1$ & $24,713.32$ & 200.06 & 0.3596 & 77.145 & 5.234 & 42.4298 \\
10 & 6,000 & 3,600 & 763.85 & $7,873.99$ & $16,114.2$ & 32.03 & 0.426 & 15.6164 & 5.9396 & 43.3598 \\
11 & 4,000 & 1,200 & $1,418.74$ & $12,756.9$ & $26,982.56$ & 88.56 & 0.4052 & 40.7834 & 7.3194 & 60.592 \\
Min & 4,000 & 1,200 & 763.9 & $1,066.2$ & $16,114.2$ & 32.03 & 0.0832 & 15.62 & 3.987 & 42.43 \\
Max & 8,000 & 4,800 & 2057.2 & $17,060.1$ & $49,434.6$ & 377.6 & 0.5012 & 239.2 & 16.04 & 174.5 \\
Mean & $5,636.3$ & $2,072.7$ & $1,220.8$ & $8,968.8$ & $29,952.9$ & 148.6 & 0.3655 & 118.4 & 8.114 & 86.41 \\
\hline
\end{tabular}

Nd: not detected. 


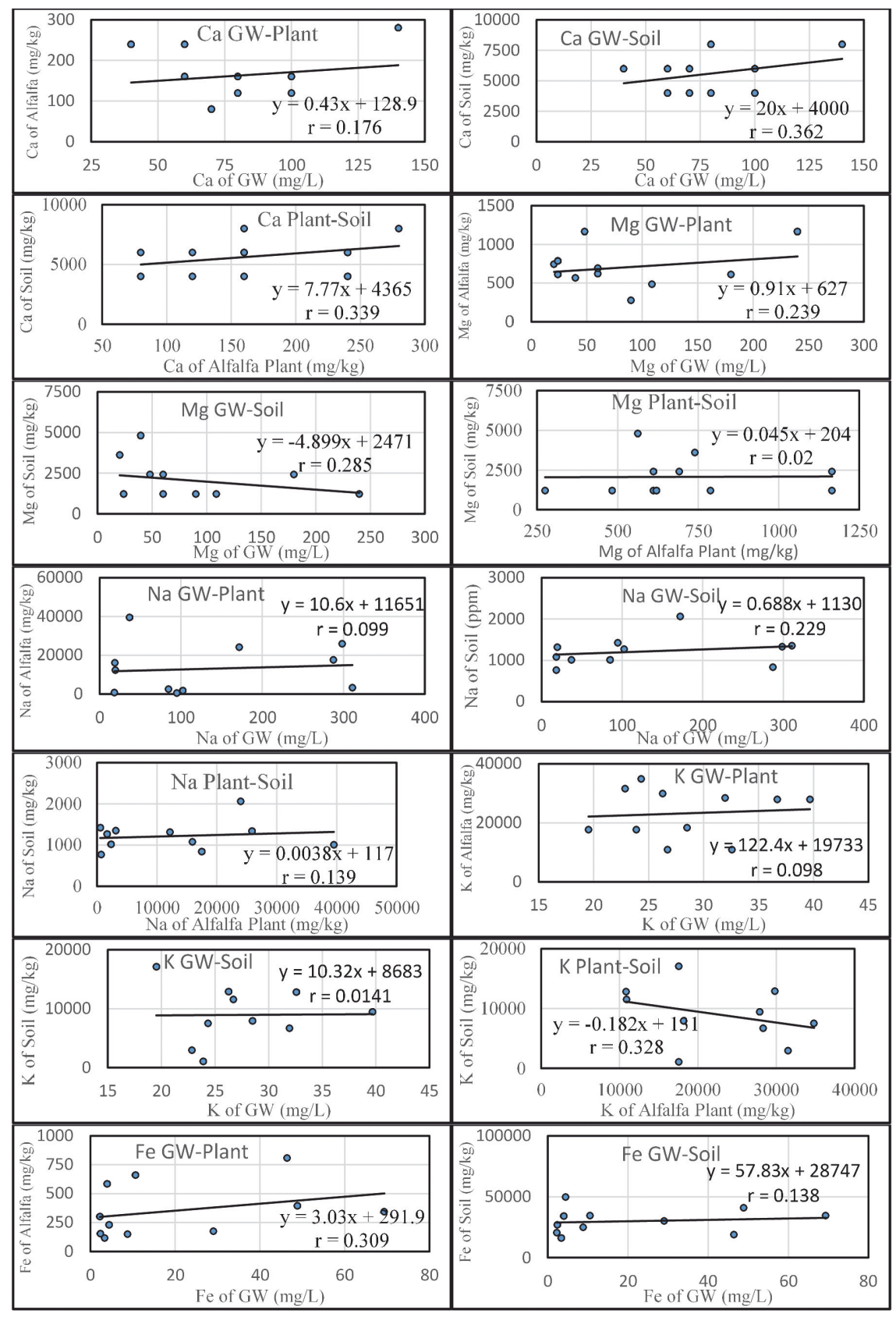

Fig. 9. Regression analyses and graphical correlation for elements relationship in groundwater, soil, and Alfalfa plants at El-Dakhla area.

Alfalfa plants (Tables 1 to 3). At some wells, zinc was not detected.

For determination of the relationship and behavior of the different elements in soil, Alfalfa plants, and groundwater, the linear regression analyses were applied (Fig. 9). They show variety in the strength of their relations. Some elements have good direct relations with positive correlation coefficient (r) values vary from 0.239 to 0.796 .

\subsection{Discussion}

\subsubsection{Groundwater properties}

The ion exchange between the groundwater and its water-bearing layers or aquifer materials during its travel process and flow path can be illustrated, using Chloroalkaline indices (CAI1 \&2) of Base Exchange. If there is an ionic exchange between $\mathrm{Ca}$ or $\mathrm{Mg}$ in the groundwater with $\mathrm{Na}$ and $\mathrm{K}$ in the groundwater-bearing layers, both the 


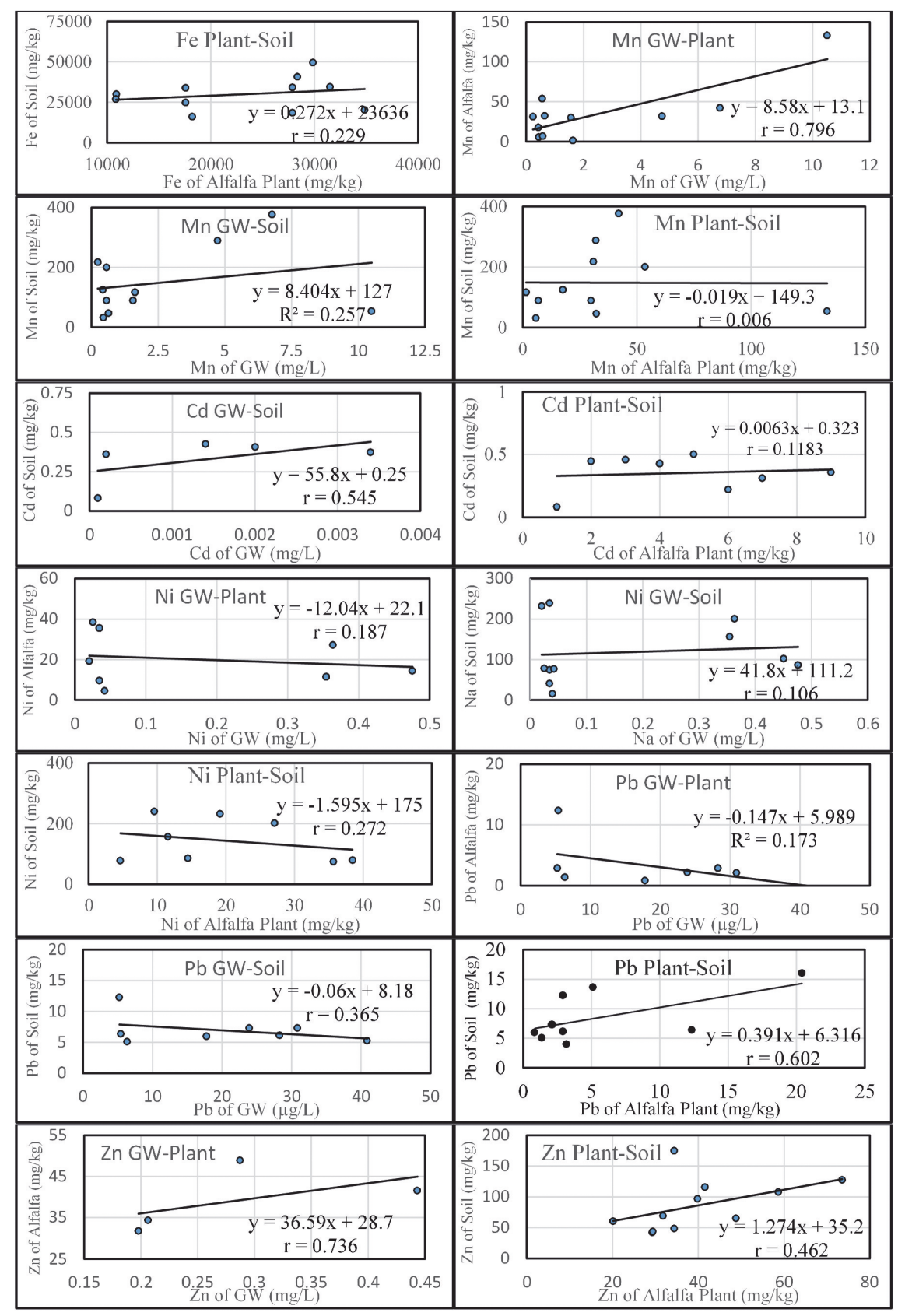

Fig. 9. Continued.

indices (Chloro-alkaline indices (CAI1 \&2)) have negative values. While, if there is a reverse ion exchange, both indices have positive values (Schoeller 1967).

Most groundwater samples have negative CAI1 and CAI2 values $(60 \%)$ indicate that there are strong exchanges between $\mathrm{Ca}$ and $\mathrm{Mg}$ from the groundwater with $\mathrm{Na}$ and $\mathrm{K}$ from the aquifer material (Fig. 3). While the rest of the studied samples (with positive values) indicates the reverse of this trend of ion exchange (Table 4).
In groundwater, the estimated hypothetical salt groups indicate the existence of different salts dissolved in the studied groundwater. They estimated salts are arranged according to their predominant as $\mathrm{MgSO}_{4}, \mathrm{NaCl}, \mathrm{CaSO}_{4}$, $\mathrm{Ca}\left(\mathrm{HCO}_{3}\right)_{2}, \mathrm{KCl}, \mathrm{Na}_{2} \mathrm{SO}_{4}$, and $\mathrm{MgCl}_{2}$ where the average equivalent percentage of these salts are $31.02 \%, 22.77 \%$, $18.43 \%, 12.74 \%, 5.65 \%, 5.21 \%$, and $4.19 \%$ respectively (Table 5). 
Table 4. Chloro-alkaline indices (CAI1 and CAI2) and ion exchange process

\begin{tabular}{cccc}
\hline $\begin{array}{c}\text { chloro-alkaline } \\
\text { indices / S. no. }\end{array}$ & $\begin{array}{c}\mathrm{CAI} 1 \\
\left(\mathrm{C} 1^{-}\right)-\left(\mathrm{Na}^{+}+\mathrm{K}^{+}\right) /\left(\mathrm{Cl}^{-}\right)\end{array}$ & $\begin{array}{c}\mathrm{CAI} 2 \\
\left(\mathrm{Cl}^{-}\right)-\left(\mathrm{Na}^{+}+\mathrm{K}^{+}\right) /\left(\mathrm{SO}_{4}{ }^{-}+\mathrm{HCO}_{3}{ }^{-}\right)\end{array}$ & Ion exchange process \\
\hline 1 & -0.12 & -0.09 & $\mathrm{Ca}-\mathrm{Mg}$ exchange $\mathrm{Na}-\mathrm{K}$ \\
3 & 0.27 & 0.28 & $\mathrm{Na}-\mathrm{K}$ exchange Ca $-\mathrm{Mg}$ \\
4 & 0.08 & 0.07 & $\mathrm{Na}-\mathrm{K}$ exchange Ca $-\mathrm{Mg}$ \\
5 & -1.79 & -0.14 & $\mathrm{Ca}-\mathrm{Mg}$ exchange $\mathrm{Na}-\mathrm{K}$ \\
6 & 0.37 & 0.15 & $\mathrm{Na}-\mathrm{K}$ exchange $\mathrm{Ca}-\mathrm{Mg}$ \\
7 & 0.25 & 0.41 & $\mathrm{Ca}-\mathrm{Mg}$ exchange $\mathrm{Ca}-\mathrm{Mg}$ \\
8 & -0.42 & -0.07 & $\mathrm{Ca}-\mathrm{Mg}$ exchange $\mathrm{Na}-\mathrm{K}$ \\
9 & -0.71 & -0.16 & $\mathrm{Ca}-\mathrm{Mg}$ exchange $\mathrm{Na}-\mathrm{K}$ \\
10 & -0.07 & -0.03 & $\mathrm{Ca}-\mathrm{Mg}$ exchange $\mathrm{Na}-\mathrm{K}$ \\
11 & -0.90 & -0.14 & $\mathrm{Ca}-\mathrm{Mg}$ exchange $\mathrm{Na}-\mathrm{K}$ \\
\hline
\end{tabular}

Table 5. The percentage of hypothetical salt combination of the groundwater

\begin{tabular}{|c|c|c|c|c|c|c|c|}
\hline S. no. & $\mathrm{KCl}$ & $\mathrm{NaCl}$ & $\mathrm{Na}_{2} \mathrm{SO}_{4}$ & $\mathrm{MgCl}_{2}$ & $\mathrm{MgSO}_{4}$ & $\mathrm{CaSO}_{4}$ & $\mathrm{Ca}\left(\mathrm{HCO}_{3}\right)_{2}$ \\
\hline 1 & 3.4 & 41.1 & 4.5 & 0.0 & 32.8 & 17.5 & 0.7 \\
\hline 2 & 2.7 & 35.3 & 0.0 & 13.7 & 37.9 & 8.4 & 2.0 \\
\hline 3 & 2.4 & 38.6 & 0.0 & 5.0 & 39.1 & 13.4 & 1.5 \\
\hline 4 & 5.6 & 1.6 & 12.8 & 0.0 & 35.3 & 22.2 & 22.5 \\
\hline 5 & 8.1 & 10.3 & 0.0 & 11.3 & 28.1 & 17.5 & 24.7 \\
\hline 6 & 3.4 & 42.8 & 0.0 & 16.1 & 26.3 & 0.0 & 11.4 \\
\hline 7 & 8.3 & 5.5 & 5.5 & 0.0 & 26.7 & 26.5 & 27.5 \\
\hline 8 & 4.0 & 14.6 & 11.6 & 0.0 & 28.9 & 37.8 & 3.1 \\
\hline 9 & 4.0 & 26.8 & 2.4 & 0.0 & 39.1 & 22.2 & 5.5 \\
\hline 10 & 11.8 & 1.9 & 10.9 & 0.0 & 27.1 & 14.2 & 34.1 \\
\hline 11 & 8.4 & 32 & 9.6 & 0.0 & 19.9 & 23.0 & 7.1 \\
\hline Average & 5.65 & 22.77 & 5.21 & 4.19 & 31.02 & 18.43 & 12.74 \\
\hline
\end{tabular}

Hypothetical salt combinations of the groundwater are classified into following assemblages:

- $\mathrm{MgSO}_{4}>\mathrm{Ca}\left(\mathrm{HCO}_{3}\right)_{2}>\mathrm{CaSO}_{4}$ (samples no. 4, 5, \& 7).

- $\mathrm{MgSO}_{4}>\mathrm{NaCl}>\mathrm{CaSO}_{4}$ (samples no. $3 \&$ 9).

$-\mathrm{MgSO}_{4}>\mathrm{NaCl}>\mathrm{MgCl}$ (sample no. 2).

- $\mathrm{NaCl}>\mathrm{MgSO}_{4}>\mathrm{CaSO}_{4}$ (samples no. $1 \& 11$ ).

- $\mathrm{NaCl}>\mathrm{MgSO}_{4}>\mathrm{MgCl}$ (sample no. 6).

$-\mathrm{CaSO}_{4}>\mathrm{MgSO}_{4}>\mathrm{NaCl}$ (sample no. 8).

Based on the plots of TDS vs. $\mathrm{Na}+\mathrm{K} /(\mathrm{Na}+\mathrm{K}+\mathrm{Ca})(\mathrm{Gibbs}$ 1970) that decipher the causes of groundwater chemistry changes, most of the study samples were fall in the rockwater interaction field (Fig. 2), with some samples fall in the evaporation category. These results emphasize that two major processes are affecting the groundwater chemistry in the study area; the interaction between the groundwater and its surrounding rocks and a little effect of the evaporation process.

Cluster analysis illustrates grouped and strongly related to each other between different elements as Fe-Mn, Ni-Zn$\mathrm{Cu}$, and $\mathrm{Pb}-\mathrm{Cd}$.

The range of slightly acid water $\mathrm{pH}$ extends from 6.01 to 6.5 , moderately acidic water $\mathrm{pH}$ range from 5.5-6, extremely acidic to strongly acidic water $\mathrm{pH}$ less than 5.5 (US EPA 2003, 2004; US Soil Survey Manual 2018). Accordingly, $27.3 \%$ of groundwater samples are extremely acidic to strongly acidic water, $9.1 \%$ moderately acidic water, 27.3 slightly acid water, and the rest of the collected samples (36.4\%) are neutral water have $\mathrm{pH}$ more than 6.5. So that, extremely acidic to strongly acidic groundwaters that have $\mathrm{pH}$ less than $5.5 \mathrm{pH}$ vary from 3.43 to 4.06 at wells 1, 2, and 3) are not suitable for irrigation purposes 
however, they actually use in the study area. Furthermore, acidity water critical and effect on studied plant growth or the plants in arid area., increase soil acidification, and corrosion or damage metal infra-structure (Fig. 4).

The $\mathrm{pH}$ levels can influence by the dissolved constituents in groundwater. Low $\mathrm{pH}$ and acidity water is due to dissolved carbon dioxide (form a weak carbonic acid), organic acids (from degraded organic matter), or by oxidation of sulfide minerals (Hem 1985, Davis and Deweist 1966).

Oxidation of pyrite and sulfide minerals generates sulfuric acid and increases the water acidity as in equations $(8 \&$ 9). Pyrite oxidation with aqueous solutions or in the presence of water-containing acid $\left(\mathrm{H}^{+}\right)$produces sulfuric acid, dissolved iron $\mathrm{Fe}(\mathrm{II})$, and sulfates $\left(\mathrm{SO}_{4}{ }^{2-}\right)$ equations (8\& $\&$ ).

$$
\begin{aligned}
& 2 \mathrm{FeS}_{2}(\mathrm{~s})+7 \mathrm{O}_{2}(\mathrm{~g})+2 \mathrm{H}_{2} \mathrm{O} \rightarrow 2 \mathrm{Fe}^{2+}+4 \mathrm{H}^{+}+4 \mathrm{SO}_{4}{ }^{2-} \\
& 2 \mathrm{FeS}_{2}(\mathrm{~s})+7 \mathrm{O}_{2}(\mathrm{~g})+2 \mathrm{H}_{2} \mathrm{O} \rightarrow 2 \mathrm{FeSO}_{4}+2 \mathrm{H}_{2} \mathrm{SO}_{4}
\end{aligned}
$$

Many studies have been conducted on the mechanism in which pyrite oxidized in an aqueous medium (as McKibben et al., 1986; Holmes and Crundwell 2000; Nicol and Lázaro 2002; Hu et al., 2004; Dos Santos et al., 2016).

The most common source of acidity and low $\mathrm{pH}$ in groundwater is dissolved carbon dioxide and form a weak carbonic acid (Equation 10).

$$
\mathrm{CO}_{2}(\mathrm{aq})+2 \mathrm{H}_{2} \mathrm{O} \leftrightarrow \mathrm{H}_{2} \mathrm{CO}_{3}
$$

Carbon dioxide enters the water through equilibrium with the air (Equation 11), biological degradation involving organic matter $\mathrm{CH}_{2} \mathrm{O}$ (Equation 12), inorganic equilibrium reactions as dissolve calcite (Equation 13) and dolomite (Equation 14) (BGS DPHE 2001, IPCC 2005, Mitchell et al., 2010, Othman et al., 2018).

$$
\begin{aligned}
& \mathrm{CO}_{2}(\mathrm{aq}) \leftrightarrow \mathrm{CO}_{2}(\mathrm{~g}) \\
& \mathrm{CH}_{2} \mathrm{O}+\mathrm{O}_{2}(\mathrm{aq}) \leftrightarrow \mathrm{CO}_{2}(\mathrm{aq})+\mathrm{H}_{2} \mathrm{O} \\
& \mathrm{CaCO}_{3}(\mathrm{~s})+\mathrm{CO}_{2}(\mathrm{aq})+\mathrm{H}_{2} \mathrm{O} \leftrightarrow \mathrm{Ca}^{2+}(\mathrm{aq})+2 \mathrm{HCO}_{3}^{-}(\mathrm{aq})
\end{aligned}
$$

$\mathrm{CaMg}\left(\mathrm{CO}_{3}\right)_{2}(\mathrm{~s})+\mathrm{CO}_{2}$ (aq) $+\mathrm{H}_{2} \mathrm{O} \leftrightarrow \mathrm{Ca}^{2+}(\mathrm{aq})+$ $\mathrm{Mg}^{2+}(\mathrm{aq})+2 \mathrm{HCO}_{3}^{-}(\mathrm{aq})$

Organic acids from the degradation of organic matter can increase groundwater acidity. The decomposition of organic sulfur is considered a source for H2S (Equation 15).
As dissolved $\mathrm{H}_{2} \mathrm{~S}$ gas comes in contact with dissolved $\mathrm{O}_{2}$, oxidation generates acid $\left(\mathrm{H}^{+}\right)$in the groundwater according to a simplified reaction in equation 16 (Lovley 1993, Pallud and Van Cappellen 2006, Mayrhofer et al., 2014).

$$
\begin{aligned}
& 2 \mathrm{CH}_{2} \mathrm{O}(\mathrm{s})+\mathrm{SO}_{4}{ }^{2-}(\mathrm{aq}) \leftrightarrow \mathrm{H}_{2} \mathrm{Sg}+2 \mathrm{HCO}_{3}{ }^{-}(\mathrm{aq}) \\
& \mathrm{H}_{2} \mathrm{~S}(\mathrm{~g})+2 \mathrm{O}_{2}(\mathrm{~g}) \leftrightarrow 2 \mathrm{H}^{+}+\mathrm{SO}_{4}{ }^{2-}
\end{aligned}
$$

Langelier Saturation Index (LSI) and Ryznar Stability Index (RSI) were used to detect groundwater corrosivity. According to the (LSI) and based on the classification of Carrier, A.C.C. (1965), all groundwaters lead to serious corrosion action (LSI values $<-0.5$ ) as shown in Figure (5) for the infrastructure in the study area. This result is compatible with calculated RSI where $63.6 \%$ of groundwaters lead to intolerable corrosion and $36.4 \%$ lead to heavy corrosion.

Plotting electrical conductivity and the sodium-adsorption ratio of the water samples to detect their quality for irrigation (Fig. 6.a) indicate that the excessive amount of TDS can be one of the major problems with water used for irrigation.

Electric conductivity and sodium percentage values of groundwater at El-Dakhla Oasis plotted in Wilcox (1955) diagram (Fig. 6.b) and it shows that $70 \%$ of groundwater samples in the study area lie in excellent to good category, $17 \%$ locate in good to permissible, $4 \%$ are permissible to doubtful class, $2 \%$ are unsuitable to doubtful water, and $7 \%$ located in unsuitable for irrigation purposes category (wells no. 3, 9, and 13).

4.2.2. Major elements in the soil, Alfalfa plants, and groundwater

The Ca-distribution map in groundwater (Fig. 10.a) indicates that the highest values observed in the central part and the lowest concentrations are located in the southeastern and northwestern parts. The distribution map of calcium in soil (Fig. 11.a) and plant (Fig. 12.a) are compatible. Where the highest concentrations are in the central part, and the lowest values observed in the southern and northern parts.

The distribution map of magnesium in groundwater (Fig. 10.b), in soil (Fig. 11.b), and in the Alfalfa plants (Fig. 12.b) have the same behavior. Where, the highest concentrations concentric in the central part, and the lowest values located in the southern and northern parts.

The distribution map of sodium in groundwater (Fig. 10.c), 

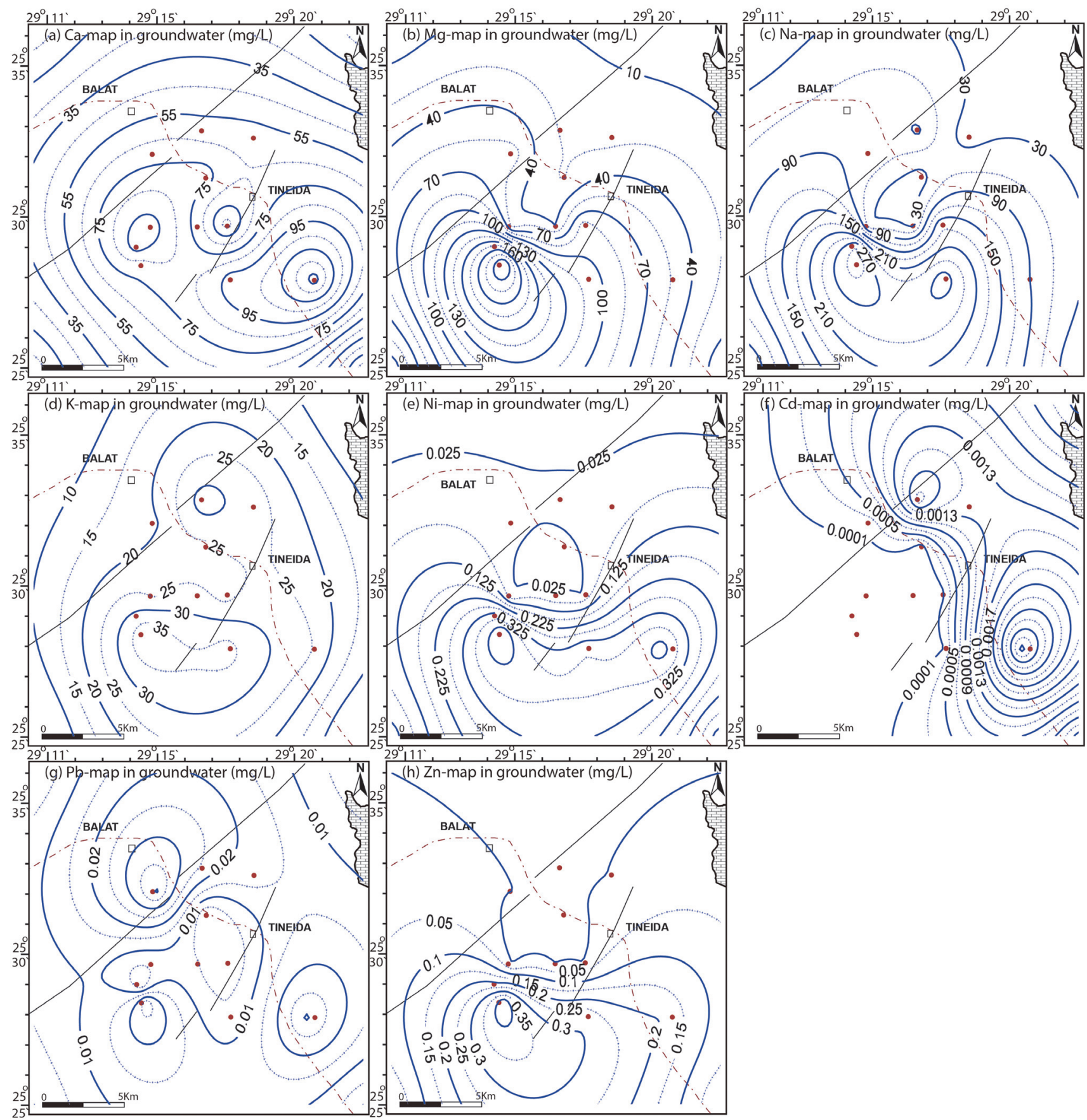

Fig. 10. Elements distribution contour maps in groundwater.

in soil (Fig. 11.c), and in the Alfalfa plants (Fig. 12.c) are compatible. Where, the highest concentrations concentric in the central part, and the lowest values located in the southern and northern parts. Most sodium, magnesium, calcium, and potassium concentrations are below the acceptable limit for drinking water according to World Health Organization (WHO 2011).
4.2.3. Influence of Heavy metal contents in Soil, Alfalfa Plants, and Groundwater

\section{Lead $(\mathrm{Pb})$}

In the earth's crust, lead is usually found as a mineral combined with other elements, such as carbonate $\left(\mathrm{PbCO}_{3}\right)$, or sulphate $\left(\mathrm{PbS}, \mathrm{PbSO}_{4}\right)$ and ranges from 10.0 to 30.0 $\mathrm{mg} / \mathrm{kg}$ in the earth's crust (USDHHS 2007). For surface 

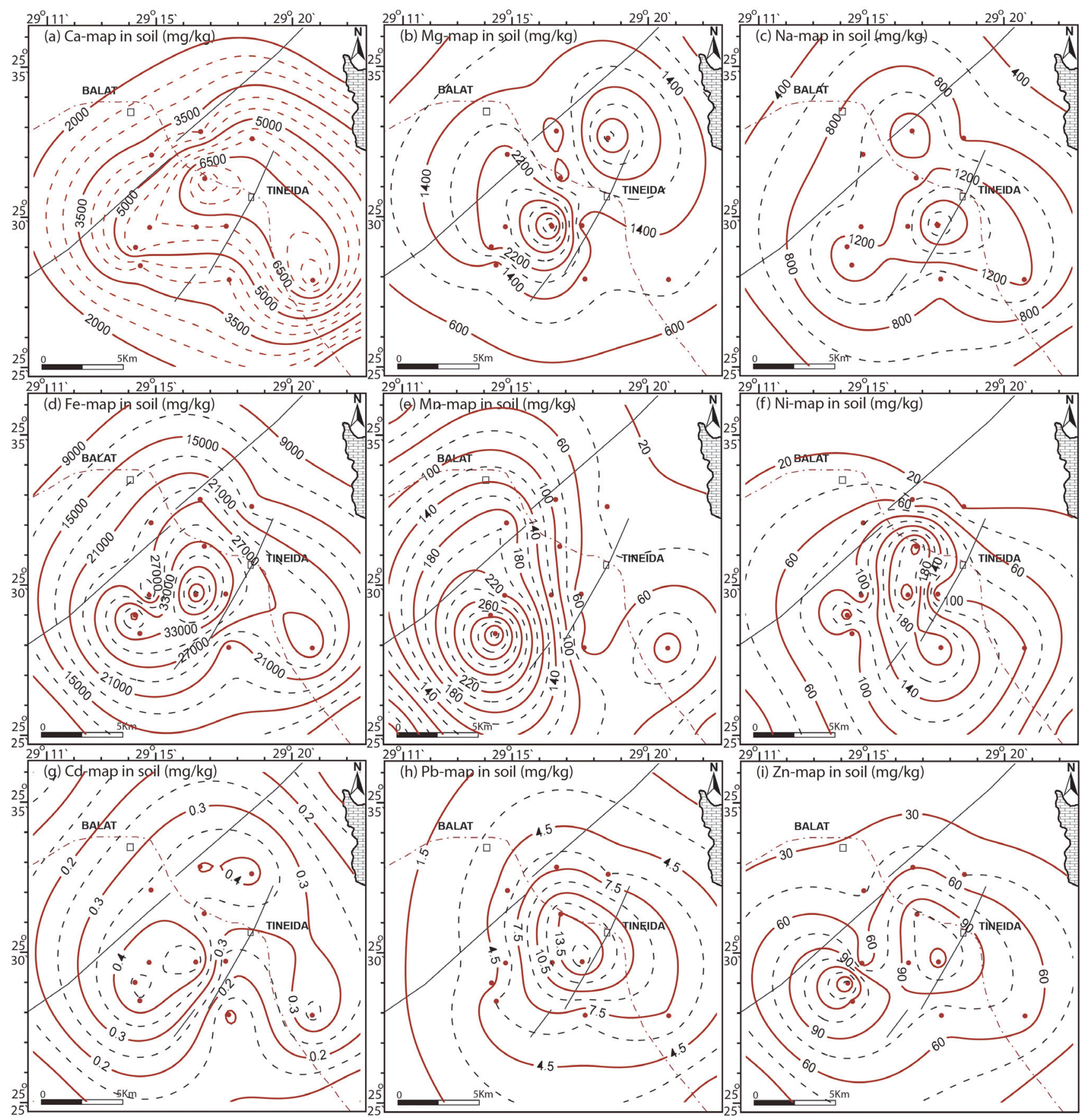

Fig. 11. Elements distribution contour maps in soil.

soils worldwide, $\mathrm{Pb}$ varied from 10.0 to 67.0 with an average of $32.0 \mathrm{mg} / \mathrm{kg}$ (Kabata-Pendias and Pendias 2001). The concentration of $\mathrm{Pb}$ in most groundwater sampling sites (45\%) exceeds the standard limit of WHO (2011) which is $0.01 \mathrm{mg} / \mathrm{L}$ (Fig. 7.a). Furthermore, the rest of the groundwaters are more close to the WHO standard limit. This result reflects that $45 \%$ of groundwaters in the study area are not suitable shouldn't use for drinking.

The lower $\mathrm{Pb}$ values from the standard limit of WHO are located in the central part where the more toxic and exceed the upper limit of WHO are in southern and northern parts as shown in the $\mathrm{Pb}$ groundwater distribution map (Fig. 10.g). The high concentration of $\mathrm{Pb}$ in groundwater affect its concentration in the soil and Alfalfa plants. The 

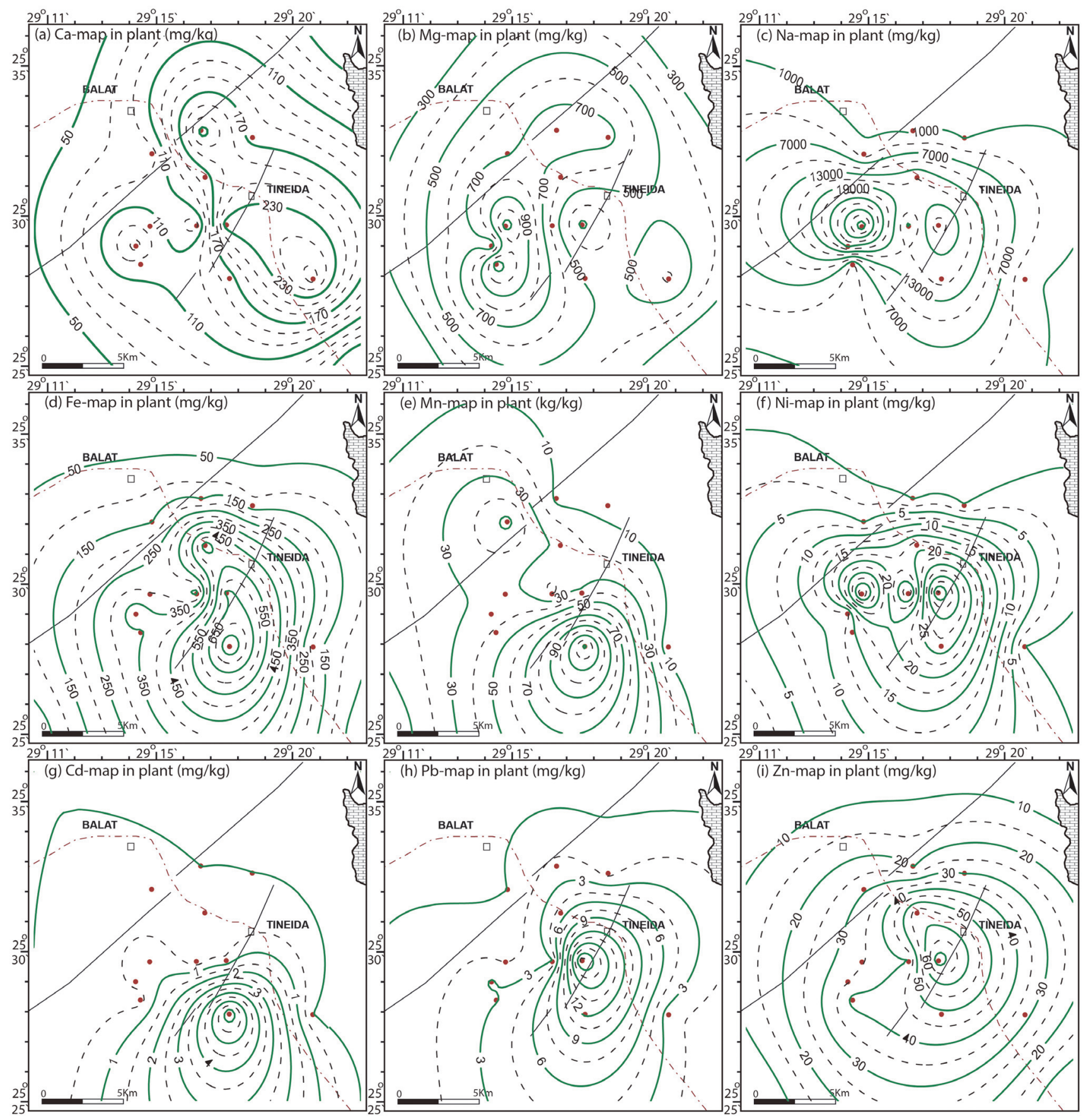

Fig. 12. Elements distribution contour maps in Alfalfa plants.

$\mathrm{Pb}$ distribution maps in the soil (Fig. 11.h) and in Alfalfa plants (Fig. 12.h) are compatible. Where the lowest $\mathrm{Pb}$ concentrations concentric in the central part and the highest values were observed in the southern and northern parts. The relation between $\mathrm{Pb}$ in the soil and Alfalfa plants in direct relation on most sides $(r=0.625)$ reflect the effect of $\mathrm{Pb}$ in the soil to its concentration in Alfalfa plants grown in the study area.

\section{Nickel (Ni)}

Nickel minerals will release $\mathrm{Ni}^{2+}$ upon weathering, which may precipitate with $\mathrm{Fe}$ and $\mathrm{Mn}$ oxides, or be adsorbed onto clay and organic fractions (Kabata-Pendias and Pendias 2001). The maximum limit for using water in drinking is 
$0.07 \mathrm{mg} / \mathrm{L}$ (WHO 2011). Accordingly, 36\% of groundwater samples are unsuitable for drinking water and lie above the upper limit (wells no. 1, 2, 3, and 8; Fig. 7.b).

The nickel distribution map in groundwater (Fig. 10.e) indicates that all southeastern parts are above the upper limit for drinking and the high nickel directions are inside. The central part is characterized by low nickel values except for wells no. 11, 13, and 38 (high nickel values). All northwestern parts are less than the upper limit for drinking and suitable for drinking. In the soils, the $\mathrm{Ni}$ distribution map (Fig. 11.f) indicates the presence of high $\mathrm{Ni}$ at the center of the study area, and the low directions are outside. In Alfalfa grown in the study area, the Nimap (Fig. 12.f) has the same behavior of Ni-map in soils that the high nickel values are concentric along the center. The maximum concentration of Nickel for irrigation is 0.2 $\mathrm{mg} / \mathrm{L}$ according to Food and Agriculture Organization (FAO 1985). Accordingly, $36 \%$ of groundwaters are not suitable for irrigation (Fig. 7.b). It strongly recommended treatment before use for irrigation purposes. It can make problems, especially with long-term usage.

\section{Cadmium (Cd)}

The weathering at different phases will release $\mathrm{Cd}^{2+}$ into the solution, which can absorb by plant roots. Even if $\mathrm{Cd}$ in solution has a low concentration, it will form organic chelates and complex ions in soil (Kabata-Pendias and Pendias 2001). The environment contaminates by $\mathrm{Cd}$ through fertilizers and wastewater (WHO 2011). The variation of cadmium concentration in groundwater may be affected by the seepage from two sewage stations located in the study area.

The cadmium in groundwaters lies under the permissible limit for drinking water except well no. 8; and lie under the permissible limit for irrigation (Fig. 7.c). The cadmium distribution maps in groundwater (Fig. 10.f) displayed that the highest values were concentric in the central and southeastern parts. The $\mathrm{Cd}$ distribution maps in soil (Fig. 11.g) and in Alfalfa plants (Fig. 12.g) have the same directions of high Cd-values (to the central part) and the low Cd-values (to the north and northwest directions).

\section{Zinc (Zn)}

Zinc can be released by the weathering of zinc minerals, which is the most common and mobile zinc ion in soil and the main form utilized by plants (Kabata-Pendias and Pendias 2001). The maximum limit for using water in drinking is $0.01 \mathrm{mg} / \mathrm{L}$ for zinc (WHO 2011). Accordingly, some of the groundwater samples (samples no. 1, 2, 3, and 8) are unsuitable for drinking water and lie above the upper limit (Fig. 7.d). The maximum concentration of zinc for irrigation is $2.0 \mathrm{mg} / \mathrm{L}$ (FAO 1985), so that, all waters have $\mathrm{Zn}$ less than $2.0 \mathrm{mg} / \mathrm{L}$ and suitable for irrigation (Fig. 7.d). The highest concentrations concentric in the central part in the study area while the lowest values detected in southern and northern parts as shown in the zinc distribution map in groundwater (Fig. 10.h), in soil (Fig. 11.i), and in Alfalfa plants (Fig. 12.i).

\section{Iron $(\mathrm{Fe})$}

The maximum concentration of iron for irrigation is 5.0 $\mathrm{mg} / \mathrm{L}$ (FAO 1985). Consequently, $73 \%$ of groundwaters are unsuitable for irrigation and the others are more close to the standard upper limit. Figure (7.e) shows that the chemical analyses of iron in groundwater samples in the study area lie above the acceptable limit of drinking water according to (WHO 2011). Therefore, all water can't use for drinking purposes. It strongly recommended preventing the use of these groundwaters as a source of drinking water before treatment.

The distribution map of iron in soil (Fig. 11.d) and in Alfalfa plants (Fig. 12.d) are compatible. Where, the highest concentrations concentric in the central part and the lowest values detected in the northern, northwestern, and northeastern parts. The relation between the concentration of iron in the groundwaters and Alfalfa plants are weak direct relation $(r=0.309)$ may be due to a few effects of iron in groundwater to its concentration in Alfalfa plants.

\section{Manganese (Mn)}

The $\mathrm{Mg}$ contents in groundwater indicate that all groundwater is unsuitable for drinking water except well no. 4 (Fig. 7.f) and lie above the upper limit $(0.4 \mathrm{mg} / \mathrm{L})$ of WHO (2011). It strongly recommended treatment before use for drinking purposes. The Mn contents in groundwaters indicate that also all groundwaters are unsuitable for irrigation and lie above the permissible limit $(0.2 \mathrm{mg} / \mathrm{L}$, FAO 1985). It strongly recommended treatment before use for irrigation purposes.

The soils Mn-map (Fig. 11.e) shows a general increase 
toward the central part and decreases toward the north, northeast, and east parts. In Alfalfa plants Mn-map (Fig. 12.e), Mn general increase at the southern middle part and decrease toward the northern and eastern directions. The relation between $\mathrm{Mn}$ in groundwaters and Alfalfa plants is direct relation $(r=0.625)$ indicate the effect of $\mathrm{Mn}$ in groundwater to its concentration in Alfalfa plants.

\subsubsection{Elements Relationship in Soil, Alfalfa Plants, and} Groundwater

To determine the relationship and behavior of some elements in soil, Alfalfa plants and groundwater in ElDakhla Oasis area, Ca, Na, Mg, K, Cd, Fe, Ni, Mn, Zn, and $\mathrm{Pb}$ were analyzed. Figure (8) shows a direct relationship between most of these elements in different locations along with their concentrations in the soil, Alfalfa plants, and groundwater. In a few parts of the study area, some elements have weak or no relationship due to changes in the soil chemical composition or local conditions. The exist of elements in groundwater affects their contents in plants and soils.

A regression equation is a statistical technique used to discover a mathematical relationship between two variables using a set of individual data points. It is used to explain or predict the behavior of a dependent variable. The linear regression was applied to determine the relationship and behavior of some elements as $\mathrm{Ca}, \mathrm{Na}, \mathrm{Mg}, \mathrm{K}, \mathrm{Cd}, \mathrm{Fe}, \mathrm{Ni}$, $\mathrm{Mn}, \mathrm{Zn}$, and $\mathrm{Pb}$ in soil, Alfalfa plants, and groundwater (Fig. 9).

Applying the regression equations to study the behavior of different elements in groundwater and Alfalfa plants indicate the following:

- Some elements have good direct relations with positive correlation coefficient ( $r$ ) as $\mathrm{Mn}, \mathrm{Zn}, \mathrm{Fe}$, and $\mathrm{Mg}$ (correlation coefficient values are 0.796, 0.736, 0.309, and 0.239 respectively). The result reflects the effect of these elements in the groundwater on its concentration in Alfalfa plants in the study area.

-Weak direct relations with positive correlation coefficient (r) were detected between some elements as $\mathrm{Ca}, \mathrm{Na}$, and $\mathrm{K}$ ( $\mathrm{r}$ values are $0.176,0.099$, and 0.098 respectively). It reflects the less effect of these elements in the groundwater to its concentration in Alfalfa plants.

- In a few elements as $\mathrm{Cd}, \mathrm{Ni}$, and $\mathrm{Pb}$ have no relationship due to changes in groundwater composition or local conditions.

Using regression equations for elements behavior in groundwater and soil detect the following:

- Good direct relations with positive correlation coefficient detected at $\mathrm{Cd}, \mathrm{Ca}$, and $\mathrm{Mn}$ (correlation coefficient values are $0.545,0.362$, and 0.257 respectively). It reflects the effect of these elements in both groundwater and soil.

- Positive correlation coefficient values with weak direct relations were observed between elements as $\mathrm{Na}, \mathrm{Fe}$, $\mathrm{Ni}$, and $\mathrm{K}$ ( $\mathrm{r}$ values are $0.229,0.138,0.106$, and 0.0141 respectively) indicating less effect of these elements in the groundwater to its concentration in soil.

- $\mathrm{Mg}$ and $\mathrm{Pb}$ have no relationship due to changes in soil chemical composition.

Regression equations were applied to study the relationship of the elements in soil and Alfalfa plants indicate the following:

- Good direct relations with positive correlation coefficient recorded in some elements as $\mathrm{Pb}, \mathrm{Zn}$, and $\mathrm{Ca}$, (correlation coefficient values are $0.602,0.462$, and 0.339 respectively). This indicates the effect of these elements in the soil on its concentration in Alfalfa plants in the study area.

-Weak direct relation and positive correlation coefficient at $\mathrm{Fe}, \mathrm{Na}, \mathrm{Cd}$, and $\mathrm{Mg}$ ( $\mathrm{r}$ values are $0.229,0.139$, 0.118 , and 0.02 respectively) were detected. It reflects the less effect of these elements in the soil to its concentration in Alfalfa plants.

- $\mathrm{K}, \mathrm{Ni}$, and $\mathrm{Mn}$ have undefined relationships due to changes in the soil composition.

\section{Conclusions}

Most groundwater is dominant by mixed Ca-Mg-SO4$\mathrm{Cl}$ type. Cluster analysis illustrates grouped and strongly related to each other between different elements as Fe-Mn, $\mathrm{Ni}-\mathrm{Zn}-\mathrm{Cu}$, and $\mathrm{Pb}-\mathrm{Cd}$. Most groundwater samples (60\%) have the tendency of ion exchange between $\mathrm{Ca}$ or $\mathrm{Mg}$ with $\mathrm{Na}$ and $\mathrm{K}$ from the aquifer material. While the rest have reverse ion exchange. $63.64 \%$ of the groundwater have low $\mathrm{pH}$ (3.03 to 6.37) and are not suitable for irrigation purposes. The high acidic water has a negative effect on 
plant growth, as well as increased soil acidity. Furthermore, the corrosive effect led to damage metal infra-structure (as detected from LSI and RSI).

The distribution map of different elements ( $\mathrm{Na}, \mathrm{Ca}, \mathrm{K}$, $\mathrm{Mg}, \mathrm{Fe}, \mathrm{Cd}, \mathrm{Mn}, \mathrm{Zn}, \mathrm{Ni}$, and $\mathrm{Pb}$ ) in groundwater, soil, and Alfalfa plants are compatible. Lead in most groundwater samples exceeds the standard limit of WHO $(>0.01 \mathrm{mg} / \mathrm{L})$ and leaving the water not suitable for drinking water. Nickel in $36 \%$ of groundwater greater than the standard limit and can't use for drinking and most of them are not suitable for irrigation. The $\mathrm{Cd}$ is less than the drinking water standard limit except for wells no. 8; and it is under the permissible limit for irrigation. Also, zinc is below the drinking water limit (except wells no. 1, 2, 3, and 8) and it is under the permissible limit for irrigation. The iron in groundwater indicates that $73 \%$ of them are unsuitable for irrigation and all water can't use for drinking purposes. Manganese in groundwater indicates that all groundwater is unsuitable for drinking (except well no. 4) and all groundwater can't use for irrigation purposes.

There are direct relationships between most elements in different sites in the soil, Alfalfa plants, and groundwater. In few parts in the study area, some elements have weak or no relationship due to changes in the soil chemical composition or local conditions. Elements relationship in groundwater shows that some elements are linked to others as $\mathrm{Na}, \mathrm{Fe}, \mathrm{Mg}, \mathrm{Zn}, \mathrm{Mn}, \mathrm{Pb}$, and Ni. In Alfalfa plants, there is an undefined relationship between the concentration of most elements except between $\mathrm{Na}, \mathrm{Mg}, \mathrm{K}$, and $\mathrm{Ni}$ (get weak relationships). Elements relationship in soil shows that some elements are linked to others as $\mathrm{Fe}, \mathrm{Ca}, \mathrm{Zn}, \mathrm{Mg}$, and $\mathrm{Pb}$, while weak or undefined relationships were detected between the others.

\section{Acknowledgement}

The authors are grateful to both Prof. Dr. Abdel Aziz Tantawy, New Valley University and Prof. Dr. Ashraf Emam, Geology Department, Faculty of Science, Aswan University for their field assessment, and fretful discussions during caring out this work. Also, we acknowledge the stuff members of the environmental and studies Lab, Aswan University for their efforts, caring out the geochemical analyses.

\section{References}

Alghobar, M.A. and Suresha, S. (2017) Evaluation of metal accumulation in soil and tomatoes irrigated with sewage water from Mysore city, Karnataka, India. Journal of the Saudi Society of Agricultural Sciences, v.16, p.49-59. doi: 10.1016/ j.jssas.2015.02.002.

Alghobar, M.A. and Suresha, S. (2017) Evaluation of metal accumulation in soil and tomatoes irrigated with sewage water from Mysore city, Karnataka, India. Journal of the Saudi Society of Agricultural Sciences, v.16, p.49-59. doi: 10.1016/ j.jssas.2015.02.002.

Barbeta, A. and Peñuelas, J. (2017) Relative contribution of groundwater to plant transpiration estimated with stable isotopes. Scientific reports, v.7, p.1-10. doi: 10.1038/s41598-017-09643-x.

BGS DPHE (2001) Arsenic contamination of groundwater in Bangladesh. In: Kinniburgh DG, Smedley PL (eds) Final report. British Geological Survey Report WC/00/19 Keyworth, UK, British Geological Survey, vol 2, p 215

Carrier A C C (1965) Handbook of Air Conditioning System Design. McGraw-Hill Books, New York, 780p.

Chaoua, S., Boussaa, S., El Gharmali, A. and Boumezzough, A. (2019) Impact of irrigation with wastewater on accumulation of heavy metals in soil and crops in the region of Marrakech in Morocco. Journal of the Saudi Society of Agricultural Sciences, v.18, p.429-436. doi: 10.1016/j.jssas.2018.02.003.

Chauhan, G. and Chauhan, U.K. (2014) Human health risk assessment of heavy metals via dietary intake of vegetables grown in wastewater irrigated area of Rewa, India. International Journal of Scientific and Research Publications, v.4, p.1-9.

Davis, S.N. and Dewiest, R.J.M. (1966) Hydrogeology, John Wiley \& Sons, Inc., New York, pp 463.

Defo, C., Yerima, B.P.K., Noumsi, I.M.K. and Bemmo, N. (2015) Assessment of heavy metals in soils and groundwater in an urban watershed of Yaounde (Cameroon-West Africa). Environmental monitoring and assessment, v.187, p.1-17. doi: 10.1007/s10661015-4292-1.

Dos Santos, E.C., de Mendonça Silva, J.C. and Duarte, H.A. (2016) Pyrite oxidation mechanism by oxygen in aqueous medium. The Journal of Physical Chemistry C, v.120, p.2760-2768. doi: 10.1021/acs.jpcc.5b10949.

Edstrom I (1998) Scale forming tendency of water. Proceedings, Adv. Eur. Geoth. Res., $2^{\text {nd }}$ Symposium, Strasbourg, Germany, 428-443.

El-Ramady, H., Abdalla, N., Kovacs, S., Domokos-Szabolcsy, E., Bákonyi, N., Fari, M. and Geilfus, C.M. (2020) Sustainable Biorefinery and Production of Alfalfa (Medicago sativa L.). Egyptian Journal of Botany, v.60, p.621-639. doi: 10.21608/ ejbo.2020.37749.1532

FAO (1985) Water quality for agriculture. Paper No. 21 (Rev. 1). UNESCO Publication. Rome.

Gad, M., El Sheikh, A. and El Osta, M. (2011) Optimal management for groundwater of Nubian aquifer in El Dakhla depression, Western Desert, Egypt. International Journal of Water Resources 
and Environmental Engineering, v.3, p.393-409. doi: 10.5897/ IJWREE11.103.

Gibbs, R. (1970) Mechanisms Controlling World's Water Chemistry, Science, v.170, p.1088-1090.

Gribovszki, Z., Szilágyi, J. and Kalicz, P. (2010) Diurnal fluctuations in shallow groundwater levels and streamflow rates and their interpretation-A review. Journal of Hydrology, v.385, p.371-383. doi: 10.1016/j.jhydrol.2010.02.001.

Hawkins, C. and Yu, L.-X. (2018) Recent progress in alfalfa (Medicago sativa L.) genomics and genomic selection. Crop Journal, v.6, p.565-575. doi: 10.1016/j.cj.2018.01.006.

Heinl, M. and Thorweihe, M. (1993) Groundwater resources and management in SW Egypt, Catena supplement, v.26, p.99-121.

Hem, J.D. (1985) Study and interpretation of the chemical characteristics of natural water (Vol. 2254). Department of the Interior, US Geological Survey.

Hermina, M. (1990) The surroundings of Kharga, Dakhla and Farafra oases. In: Said R (ed), The geology of Egypt. Balkema, Rotterdam, pp. 259-292, http://doi.org/10.1201/978020373667814.

Holmes, P.R. and Crundwell, F.K. (2000) The kinetics of the oxidation of pyrite by ferric ions and dissolved oxygen: an electrochemical study. Geochimica et Cosmochimica Acta, v.64, p.263-274. doi: 10.1016/S0016-7037(99)00296-3.

Hu, H., Chen, Q., Yin, Z., Zhang, P. and Wang, G. (2004) Effect of grinding atmosphere on the leaching of mechanically activated pyrite and sphalerite. Hydrometallurgy, v.72, p.79-86. doi: 10.1016/S0304-386X(03)00127-0.

Huang, F., Zhang, Y., Zhang, D. and Chen, X. (2019) Environmental groundwater depth for groundwater-dependent terrestrial ecosystems in arid/semiarid regions: A review. International journal of environmental research and public health, v.16, p.763. doi: 10.3390/ijerph16050763.

IPCC (Intergovernmental Panel on Climate Change) (2005) Special report on carbon dioxide capture and storage, pp. 197, 208, 390. Cambridge, UK: Cambridge University Press.

Kabata-Pendias, A. (2000) Trace Elements in Soils and Plants, $3^{\text {rd }}$ ed., CRC Press, Inc., Boca Raton, Florida.

Kumar, V., Thakur, R.K. and Kumar, P. (2019) Assessment of heavy metals uptake by cauliflower (Brassica oleracea var. botrytis) grown in integrated industrial effluent irrigated soils: A prediction modeling study. Scientia horticulturae, v.257, 108682. doi: 10.1016/j.scienta.2019.108682.

Kumari, M. and Rai, S.C. (2020) Hydrogeochemical evaluation of groundwater quality for drinking and irrigation purposes using water quality index in semi arid region of India. Journal of the Geological Society of India, v.95, p.159-168. doi: 10.1007/ s12594-020-1405-4.

Lei, Y., Hannoufa, A. and Yu, P. (2017) The use of gene modification and advanced molecular structure analyses towards improving alfalfa forage. International Journal of Molecular Sciences, v.18, p.E298. doi: 10.3390/ijms18020298.

Li, B., Wang, Y., Hill, R.L. and Li, Z. (2019) Effects of apple orchards converted from farmlands on soil water balance in the deep loess deposits based on HYDRUS-1D model. Agriculture,
Ecosystems \& Environment, v.285, 106645. doi: 10.1016/ j.agee.2019.106645.

Lovley, D.R. (1993) Anaerobes into heavy metal: dissimilatory metal reduction in anoxic environments. Trends in ecology \& evolution, v.8, p.213-217. doi: 10.1016/0169-5347(93)90102-U.

Lubczynski, M. (2009) The hydrogeological role of trees in waterlimited environments. Hydrogeology Journal, v.17, p.247. doi: 10.1007/s10040-008-0357-3.

Maihemuti, B., Simayi, Z., Alifujiang, Y., Aishan, T., Abliz, A. and Aierken, G. (2021) Development and evaluation of the soil water balance model in an inland arid delta oasis: Implications for sustainable groundwater resource management. Global Ecology and Conservation, v.25, e01408. doi: 10.1016/ j.gecco.2020.e01408.

Mayrhofer, C., Niessner, R. and Baumann, T. (2014) Hydrochemistry and hydrogen sulfide generating processes in the Malm aquifer, Bavarian Molasse Basin, Germany. Hydrogeology Journal, v.22, p.151-162. DOI 10.1007/s10040-013-1064-2.

McKibben, M.A. and Barnes, H.L. (1986) Oxidation of pyrite in low temperature acidic solutions: Rate laws and surface textures. Geochimica et Cosmochimica Acta, v.50, p.1509-1520. doi: 10.1016/0016-7037(86)90325-X.

McLaughlin, M, Parker, D. and Clarke, J. (1999) Metals and micronutrients - Food safety issues. Field Crops Research, v.60, p.143-163. doi: 10.1016/S0378-4290(98)00137-3.

Mitchell, M.J., Jensen, O.E., Cliffe, K.A. and Maroto-Valer, M.M. (2010) A model of carbon dioxide dissolution and mineral carbonation kinetics. Proceedings of the Royal Society A: Mathematical, Physical and Engineering Sciences, v.466, p.1265-1290. doi: 10.1098/rspa.2009.0349.

Nicol, M.J. and Lázaro, I. (2002) The role of EH measurements in the interpretation of the kinetics and mechanisms of the oxidation and leaching of sulphide minerals. Hydrometallurgy, v.63, p.15-22. doi: 10.1016/S0304-386X(01)00206-7.

Othman, A., Sulaiman, A. and Sulaiman, S.K. (2015) The study on the effectiveness of organic material in acid mine drainage treatment. Jurnal Teknologi, v.77, doi: 10.11113/jt.v77.5991 .

Pallud, C. and Van Cappellen, P. (2006) Kinetics of microbial sulfate reduction in estuarine sediments. Geochimica et Cosmochimica Acta, v.70, p.1148-1162. doi: 10.1016/j.gca.2005.11.002.

Qin, J., Niu, A., Liu, Y. and Lin, C. (2021) Arsenic in leafy vegetable plants grown on mine water-contaminated soils: Uptake, human health risk and remedial effects of biochar. Journal of Hazardous Materials, v.402, 123488. doi: 10.1016/ j.jhazmat.2020.123488.

Ren, D., Xu, X., Ramos, T. B., Huang, Q., Huo, Z. and Huang, G. (2017) Modeling and assessing the function and sustainability of natural patches in salt-affected agro-ecosystems: Application to tamarisk (Tamarix chinensis Lour.) in Hetao, upper Yellow River basin. Journal of Hydrology, v.552, p.490-504. doi: 10.1016/ j.jhydrol.2017.04.054.

Richard, A., Galle, S., Descloitres, M., Cohard, J.M., Vandervaere, J.P., Séguis, L. and Peugeot, C. (2013) Interplay of riparian forest and groundwater in the hillslope hydrology of Sudanian West Africa (northern Benin). Hydrology and Earth System Sciences, 
v.17, p.5079-5096. doi: 10.5194/hess-17-5079-2013.

Said, R. (1990) Geomorphology. In: Said R (ed), The geology of Egypt. Balkema, Rotterdam, pp 9-25.

Schoeller, H. (1967) Geochemistry of groundwater - an international guide for research and practice (Chap.15, pp.1-18). UNESCO.

Sefelnasr, A. (2002) Hydrogeological studies on some areas on the new Valley governorate, Western Desert, Egypt. MSc thesis, Assiut University, Egypt.

Shah, A., Niaz, A., Ullah, N., Rehman, A., Akhlaq, M., Zakir, M. and Suleman Khan, M. (2013) Comparative study of heavy metals in soil and selected medicinal plants. Journal of Chemistry, v.2013, 621265. doi: 10.1155/2013/621265.

Shebl, M.A., Kamel, S.M., Abu Hashesh, T.A. and Osman, M.A. (2008) The impact of leafcutting bees (Megachile minutissima, Megachilidae, Hymenoptera) (Radoszkowski, 1876) artificial nest sites on seed production of alfalfa, Ismailia, Egypt. Agriculture Journal, v.5, p.33-35.

Shomar, B. (2015) Geochemistry of soil and groundwater in arid regions: Qatar as a case study. Groundwater for Sustainable Development, v.1, p.33-40. doi: 10.1016/j.gsd.2015.12.005.

U.S. Salinity Laboratory Staff (1954) Diagnosis and improvement of saline and alkali soils. USDA Handbook 60, U.S. Government Printing Office, Washington, D. C.

US EPA (2003) Environmental Protection Agency: National primary and secondary drinking water standard. Office of Water (4606M) (Vol. 16). EPA 816-F-03-016.

US EPA (2004) EPA-822R04005. Drinking water standards and health advisories. National Primary Drinking Water Standards. United States Environmental Protection Agency. Washington, D.C., EUA, 20 pp. http://water.epa.gov/drink/standardsriskmanagement.cfm.

US. Soil Survey Manual (2018) U.S. Department of Agriculture
Handbook No. 18, the Soil Survey Manual, previously issued October 1962 and October 1993, 693p.

USDHHS (2007) Toxicological profile for lead. Altanta: United States Department of Health and Human Services, Agency for Toxic Substances and Disease Registry, p. 582.

WHO (World Health Organization) (2011) Guidelines for drinkingwater quality $\left(4^{\text {th }}\right.$ ed.). World Health Organization.

Wilcox, L. (1955) Classification of Irrigation Waters. U.S. Dept. Agric. Circular 969, Washinton, U. S. Dept. Agric.

Wycisk, P. (1994) Correlation of the major late Jurassic-early Tertiary low-and high stand cycles of south-west Egypt and north-west Sudan. Geologische Rundschau, v.83, p.759-772. doi: 10.1007/BF00251074.

Yin, L., Zhou, Y., Huang, J., Wenninger, J., Zhang, E., Hou, G. and Dong, J. (2015) Interaction between groundwater and trees in an arid site: Potential impacts of climate variation and groundwater abstraction on trees. Journal of Hydrology, v.528, p.435-448. doi: 10.1016/j.jhydrol.2015.06.063.

Zeng, Y., Zhao, C., Shi, F., Schneider, M., Lv, G. and Li, Y. (2020) Impact of groundwater depth and soil salinity on riparian plant diversity and distribution in an arid area of china. Scientific reports, v.10, p.1-10. doi: 10.1038/s41598-020-64045-w.

Zhang, F., Kang, J., Long, R., Yu, L.X., Wang, Z., Zhao, Z., Zhang, T. and Yang, Q. (2019) High-density linkage map construction and mapping QTL for yield and yield components in autotetraploid alfalfa using RAD-seq. BMC Plant Biology, v.19, 165. doi: 10.1186/s12870-019-1770-6

Zhang, X., Guan, T., Zhou, J., Cai, W., Gao, N., Du, H., Jiang, L., Lai, L. and Zheng, Y. (2018) Groundwater depth and soil properties are associated with variation in vegetation of a desert riparian ecosystem in an arid area of China. Forests, v.9, p.34. doi: 10.3390/f9010034. 